\title{
The use of the saber in the army of Napoleon
}

\author{
Bert Gevaert \\ Katholieke Universiteit Leuven (Belgium) \\ Hallebardiers / Sint Michielsgilde Brugge (Belgium) \\ Bert.gevaert@sint-lodewijkscollege.be
}

\begin{abstract}
Though Napoleonic warfare is usually associated with guns and cannons, edged weapons still played an important role on the battlefield. Swords and sabers could dominate battles and this was certainly the case in the hands of experienced cavalrymen. In contrast to gunshot wounds, wounds caused by the saber could be treated quite easily and caused fewer casualties. In 18th and 19th century France, not only manuals about the use of foil and epee were published, but also some important works on the military saber: de Saint Martin, Alexandre Muller... The saber was not only used in individual fights against the enemy, but also as a duelling weapon in the French army.
\end{abstract}

Keywords - saber; Napoleonic warfare; Napoleon; duelling; Material culture; Historical European Martial Arts (HEMA); History

"The sword is the weapon in which you should have most confidence,
because it rarely fails you by breaking in your hands. Its blows are the
more certain, accordingly as you direct them coolly; and hold it properly."

Antoine Fortuné de Brack, Light Cavalry Exercises, $1876^{1}$

\section{INTRODUCTION}

Though Napoleon (1769-1821) started his own military career as an artillery officer and achieved several victories by clever use of cannons, edged weapons still played an important role on the Napoleonic battlefield. Swords and sabers could dominate battles and this was certainly the case in the hands of experienced cavalrymen. The general image, although, is that Napoleonic warfare was dominated by firepower.

Smoothbore flintlock muskets indeed caused most of the wounds, but the accuracy of the weapon was strongly limited at ranges greater than $100 \mathrm{~m} .{ }^{2}$ An individual infantryman

\footnotetext{
*In writing this article I received valuable information from Matt Easton and Marcus Hampel. Special thanks go to La famille Bonaparte, Ken Broeders, illustrator, graphic novel artist/writer, and expert on Napoleonic matter.

${ }^{1}$ de Brack, Light cavalry out-posts, p. 51.

${ }^{2}$ Westwood, 'rifle', p. 375.
} 
would be very lucky if he could hit something at more than $80 \mathrm{~m}$ and at $200 \mathrm{~m}$ only a concentrated mass of soldiers could be effective, so firing muskets en masse had to be used as a military tactic. ${ }^{3}$

Some calculations estimate that only $5 \%$ of the casualties in war were caused by bullets fired at a range of about $100 \mathrm{~m}$ and that this number was reduced to $2 \%$ when the bullets were fired from up to $200 \mathrm{~m} .{ }^{4}$ Alessandro Barbero gives us other interesting numbers about the accuracy of musket fire in the Napoleonic era: only one bullet out of 459 actually hit the target at which iat was aimed. At Waterloo, where many shots were fired at close range, only one bullet out of 162 hit its target. ${ }^{5}$

In combination, however, with the bayonet, it became an important weapon in close quarter fights. Whole, well trained, divisions of soldiers armed with bayonets could even stop cavalry charges as proven at the Battle of Waterloo (18 June 1815).

Though Fortuné de Brack (see below) is quite positive about the French firearms, which he considers as "the best in Europe", ${ }^{6}$ he nevertheless puts a lot of attention to the technical problems which can arise when using these weapons: flintstones can get lost, the barrel can get dirty, the cock can fall down without you wanting it (e.g. when you are at rest), the cartridges can get wet by rain or damp, $\ldots{ }^{7}$ Louis Rilliet, second lieutenant in a cuirassiers division (1804-1814) writes about a small battle near Janowitz, known as the Battle of Katzbach (26 August 1813) where infantry soldiers could not use their muskets because of the heavy rain. ${ }^{8}$

It is also important to consider that pistols and muskets caused a lot of smoke so sometimes soldiers had the feeling that they where shooting blindfolded. This is also the reason why uniforms in the Napoleonic era had very bright colours, so soldiers could easily recognize their own regiments and certainly not shoot at them... Besides muskets, pistols were also used, but these had the huge disadvantage that they are only certain when they are fired very close to the target, but not too close because when the muzzle of the pistol touches the enemy, "the pistol may burst and wound the man firing." Thus pistols were best used in combination with the saber and to make sure you don't waste time, it was best to fasten the lanyard of the pistol so you can throw it to your left and immediately use the saber. ${ }^{10}$

\footnotetext{
${ }^{3}$ Westwood, 'musket', p. 669.

${ }^{4}$ Hughes, Firepower: weapons effectiveness on the battlefield 1630-1850, p. 127.

${ }^{5}$ Barbero, Waterloo. Het verhaal van de veldslag, p. 159.

${ }^{6}$ de Brack, Light cavalry out-posts, p. 46.

${ }^{7}$ Ibid., pp. 46-51.

${ }^{8}$ Rilliet, Journal d'un sous-lieutenant de cuirassiers, p. 81.

${ }^{9}$ de Brack, Light cavalry out-posts, p. 48.

${ }^{10}$ Ibid., p. 50.
} 
Rifles, which had grooved barrels, had a longer range and better accuracy, but the weapon was too costly and therefore it was seldom used in the French army. In contrast, the British and their allies made wide use of this weapon at the Battle of Waterloo, so their shots were more successful. ${ }^{11}$

Firearms did play a significant role on the Napoleonic battlefield (only to be surpassed by artillery) but they were not always reliable and didn't guarantee success in personal combat. It is therefore no surprise that Fortuné de Brack says that a cavalry soldier should have most confidence in his saber. ${ }^{12}$ Even modern scholars agree on this:

The cavalry's principal purpose was to attack the enemy and engange handto-hand. To that end, the most important part of a cavalryman's equipment was his sword. ${ }^{13}$

Almost every soldier in the army of Napoleon carried a saber; not only the cavalry but also the infantry had their own shorter sabers. The purpose of this article is to shed some light on the use of the saber in the army of Napoleon, especially because this year the bicentenary of the Battle of Waterloo was celebrated. Thousands of people have visited the huge reenactment (about 5000 reenactors and at least 300 horses) which took place at Waterloo on the 19th and 20th of June 2015.

\section{TRAINING WITH THE SABER}

\section{II.1. Prequel: Fencing with the smallsword and epee}

By the end of the 18th century France had a long fencing tradition: not only was it here that the most famous Italian fencer and smallsword master Domenico Angelo Tremamondo (1716-1802) studied fencing under the wing of the French master Teillagory, ${ }^{14}$ but it was also the place of origin of several fencing treatises.

Between 1623 and 1801 about 38 fencing manuals were published in France, ${ }^{15}$ most of them dealing with the smallsword - to mention only the ones published in the $18^{\text {th }}$ century - Labat (Questions sur l'art en fait d'armes ou de l'épee, Toulouse, 1701), Jean de Brye (L'art de tirer les armes, Paris, 1721), Jean Jamin de Beaupré (Méthode très facile pour former la noblesse dans l'art de l'épée, 1721), Basnières (De la beauté de l'escrime, 1732), Martin (Le maistre d'armes ou l'abrégé de l'exercice de lépée, Strassbourg, 1737), Louis Charpentier (Les vrais principes de l'épee, 1742), François Bas (Nouvelles et utiles observations pour bien tirer les armes, Basles, 1749),

\footnotetext{
11 Westwood, 'Musket', pp. 818-819.

12 de Brack, Light cavalry out-posts, p. 51.

${ }^{13}$ Haythornthwaite, Napoleonic cavalry, p. 29.

${ }^{14}$ Loades, Swords and swordsmen, p. 342.

${ }^{15}$ Briost, Drévillon, and Serna, Croiser le fer, pp. 202 and 497.
} 
Jean-Baptiste Le Perche du Coudray (L'exercice des armes ou le maniement du fleuret pour aider la mémoire de ceux qui sont amateurs de cet art, 1750), Gérard Gordine (Principes et quintessences des armes, Liège, 1754), Guillaume Danet (L'art des armes ou la manière la plus certaine de se servir utilement de l'épée soit pour attaquer, soit pour se défendre, simplifiée et démontrée dans toute son étendue et sa perfection, suivant les meilleurs principes de théorie et de pratique adoptées actuellement en France, Paris, 1766),...

In the $19^{\text {th }}$ century one of the best known French treatises was published by Antoine Texier La Boëssière (1766-1818), son of Texier la Boessière: Traité de l'art des armes, a l'usage des professeurs et des amateurs (Paris, 1818).

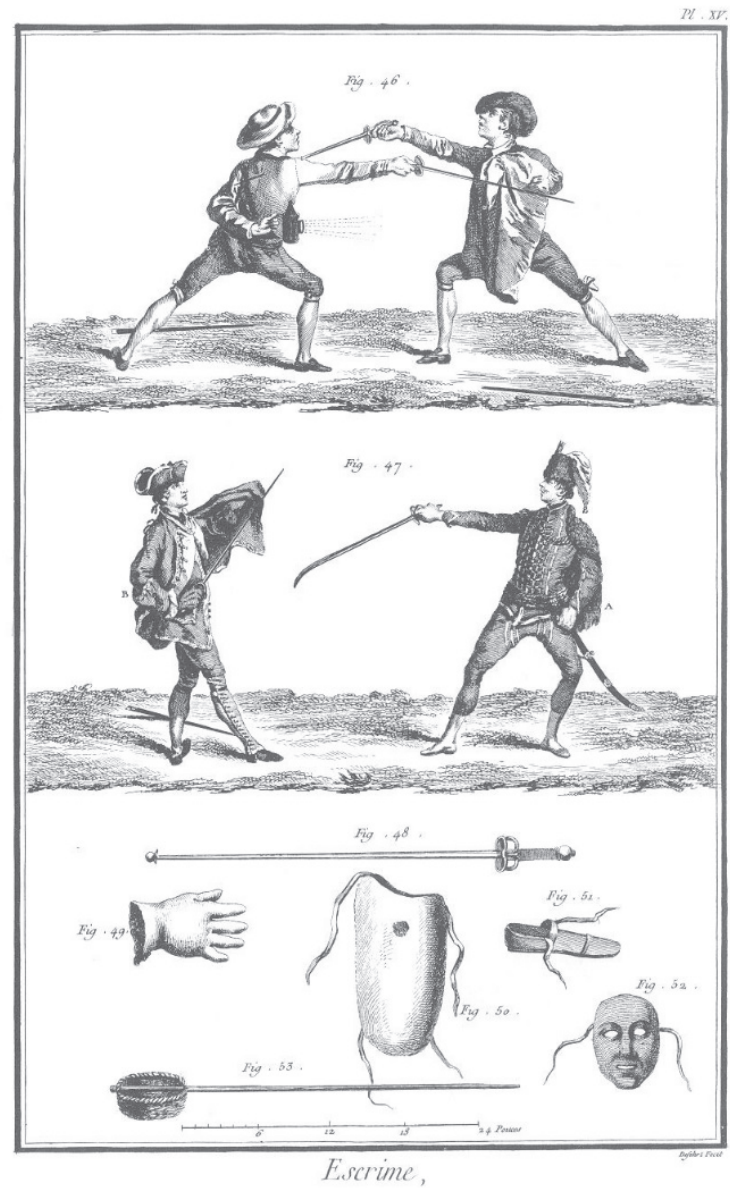

Figure 1: Fencing with the smallsword, followed by smallsword versus saber. Below: Basket hilt foil, heavily padded glove, plastron, fencing slipper, and fencing mask.

Detail from "Fencing," Diderot and d'Alambert: Encyclopédie méthodique ou dictionnaire raisonné des sciences, des arts, et des métiers (1765), plate XV. 
The importance of France as nation of fencing also explains why Angelo (Domenico Angelo Tremamondo), the "Angel of fencing" published his very influential work L'ecole des Armes (1763) in French, though he lived in England. It was he who put an emphasis on fencing as a sport and not as a martial art. ${ }^{16}$

That fencing became more and more a sport and not a deadly art, can also be explained by the use of the foil (fleuret), depicted for the first time in Philibert de la Touche, Les vrays principes de l'épée $(1667)^{17}$

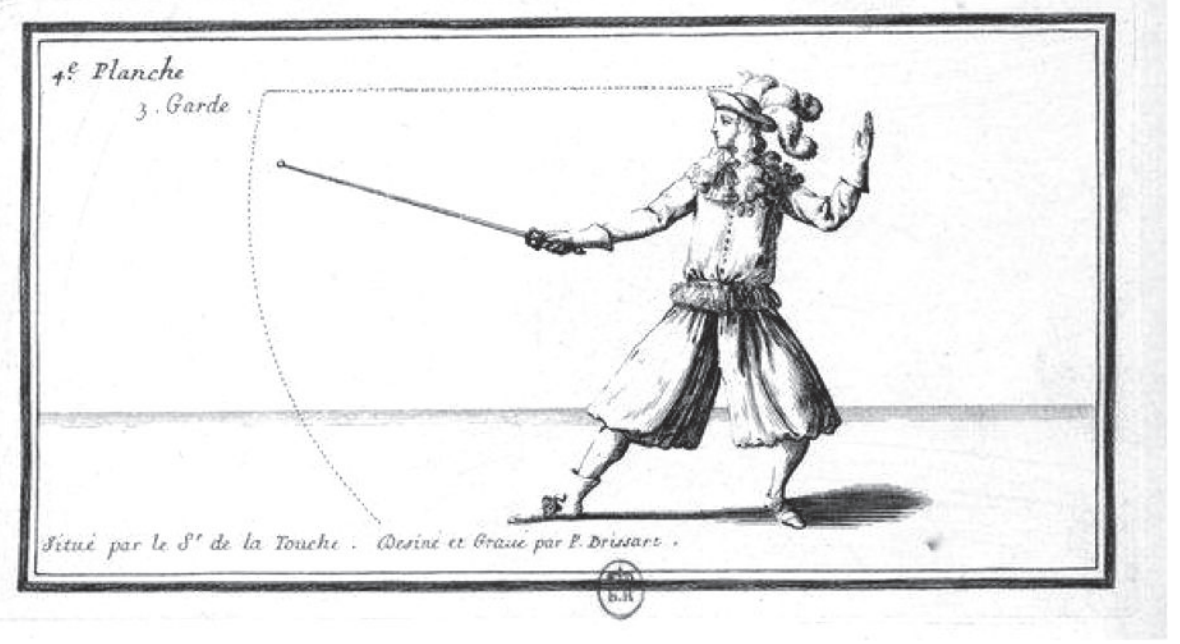

Figure 2 : Pbilibert de la Touche, Les vrays principes de l'épée (1667), plate 4.

Another French invention was the fencing mask, invented by Texier La Boessière (17231803). He introduced a mask with wire mesh and this replaced the old masks, which were made of leather or tinplate with small holes to see or with a horizontal eye slit (see illustration in the Encyclopédie of Diderot and d'Alambert). Though the new mask of Boessière offered better visibility, wearing a mask was still seen as an act of cowardice and of lack of trust in the capacities of the opponent. Here the philosophy was that a skilled fencer would not thrust his opponent in the eyes. ${ }^{18}$

France also had some brilliant fencers, including the Chevalier de Saint Georges (17451799), who was a student of Texier La Boessière, and the famous Chevalier d'Eon (17281810).

\footnotetext{
${ }^{16}$ Ibid., p. 186.

${ }^{17}$ Amberger, The secret history of the sword, p 243.

${ }^{18}$ Cohen, By the sword, p. 75.
} 
The contemporaries of d'Eon didn't know for sure if she was actually a he, but nevertheless d'Eon was not only a secret agent for France, an officer in the French army, but also a brilliant fencer. He - or she? - gave lessons in fencing and sometimes fenced for huge audiences. The most famous of these demonstrations was the bout against, the Chevalier de Saint Georges, who had the reputation of being the best fencer of his generation. All newspapers wrote about the outcome of the bout: d'Eon won with seven hits to one, ${ }^{19}$ which is a very surprising result, especially because Angelo had written about him:

(...) he surpassed all his contemporaries and predecessors. No professor or amateur ever showed so much accuracy or so much strength, such length of lunge and such quickness; his attacks were a perpetual series of hits, his parade (parries) were so closed that it was in vain to attempt to touch him - in short, he was all nerve. ${ }^{20}$

\section{II.2. The rise of the saber and saber manuals}

But French fencing also had a very important martial and military side and fencing with the foil and epee is certainly not enough to use on the battlefield. In the $18^{\text {th }}$ century a new weapon was introduced in the French world of fencing: the saber! Because of the curved blade, the prime object of this weapon was to slice and not to thrust. In its longer version it was popular in the cavalry (though they also used "sabers" with straight blades, so it's better to call these "swords"), in its shorter version it became known as the cutlass. The saber was much more durable than the epee and smallsword and also better to use against the bayonet. Quite soon, and in line with the literary tradition of Europe, the first manuals were published.

It is not my intention to provide a full list and detailled description or analyse of all French saber manuals or manuals written by soldiers who served in the army of Napoleon, but I only want to give the reader an idea of the richness of some saber treatises with a Napoleonic or French connection. Here I will present you the writings of de Saint Martin (1804), Alexandre Muller (1816), Fortuné de Brack (1831) and F.C. Cristmann (1838). I have selected these four works for the following reasons: de Saint Martin has without doubt published one of the most elaborate French treatises on saber fencing and can be situated in the middle of the reign of Napoleon (though he was not fighting or working under his command), while Muller was a soldier under Napoleon but published one of the shortest and most practical saber treatises. The work of Fortuné de Brack is not a real saber manual, but a military handbook which also contains a very short but interesting section on the use of the saber. Finally I end with Christmann, who fought in the French army, but wrote his work in German. Nevertheless, his experiences are those of a French

\footnotetext{
${ }^{19}$ Ibid., pp. 84-91.

${ }^{20}$ Ibid., p. 94.
} 
cavalryman so, in my opinion, it is a valuable source for saber fencing connected to or influenced by the army of Napoleon.

Further, it is important to note that soldiers using the saber primarily also had to be excellent horsemen, and that many manuals were also published on horsemanship. Though horsemanship was also taught by the use of manuals ${ }^{21}$ and it was in combination with the horse that the saber became most effective, I have more or less neglected this in this article because my focus is on the use of the saber on foot.

To my knowledge, French manuals didn't make much difference between extremely curved, lightly curved (demi-courbé) or even straight blades, as De La Roche-Aymon writes:

Whether a saber is straight or curved, the use of it is almost the same, with the only exception that the straight blade, independent even from the use of the edge, must use its point more, not only for the attack, but also for the riposte. ${ }^{22}$

One of the first $18^{\text {th }}$ century French fencing manuals where a saber-like weapon can be seen is written by Pierre Jacques François Girard (1736), Nouveau traité de la perfection sur le fait des armes. It focusses on fencing with the smallsword (épée de pointe seule), not only against another smallsword but also against the rapier, flail, pike and saber (espadon). ${ }^{23}$

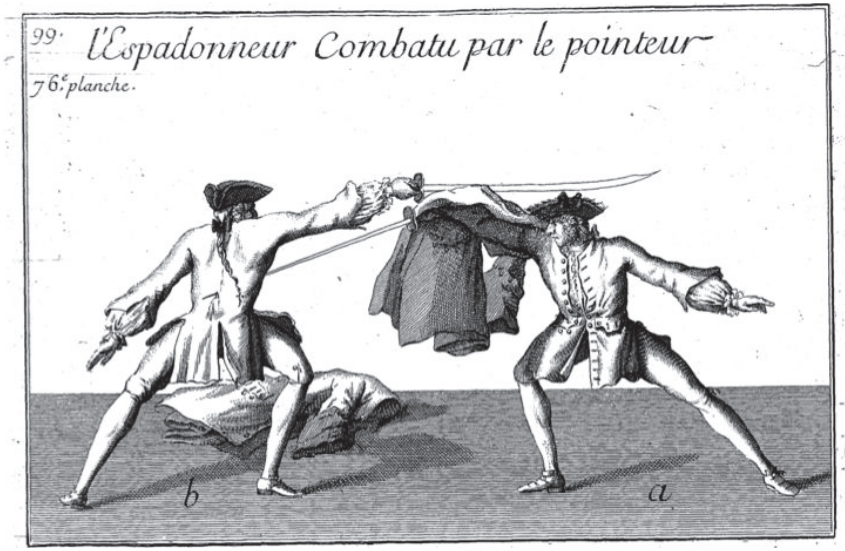

Figure 3: Girard, Nonveau traité de la perfection sur le fait des armes (1736), plate 74.

\footnotetext{
${ }^{21}$ For more info see: $\leq$ http:// fonds-ancien.equestre.info $>$.

${ }_{22}^{2}$ Que le sabre soit droit ou courbé, l'usage en est à peu près le même; à cette exception qu'avec la lame droite, indépendamment même de l'usage du taillant, on doit encore plus souvent employer la pointe, soit pour l'attaque, soit pour la riposte. de la Roche-Aymon, Troupes Légères, ou réflexions sur l'organisation, l'instruction et la tactique de l'infanterie et de la cavalerie légères, p. 301.

${ }^{23}$ Girard, Nouveau traité de la perfection sur le fait des armes.
} 


\section{II.2.1. De Saint Martin: $L$ 'art de faire des armes réduit à ses vrais principes (1804)}

The only information about M.J. de Saint Martin can be found in his own work, L'art de faire des armes réduit à ses vrais principes (The Art of Fencing Reduced to its true principles) (Vienna, 1804). He was a student of Guillaume Danet and calls himself 'ancien officier de cavallerie et Maitre d'armes Imperial (ancient cavalry officer and imperial master of arms) and elsewhere professeur imperial de L'Académie Thérésienne (Imperial professor in the Theresian Academy, this is the Austrian Academy named after empress Marie Thérèse). When his work was published he had already been in Austria for seven years, so he actually didn't serve under Napoleon. ${ }^{24} \mathrm{He}$ states that he had about 30 years of experience before he published his treatise. For the use of the saber, he claims that he wrote his own theories, after he had put his ideas in practice in real combat situations. ${ }^{25}$

His work actually consists of two parts, but with one long and very interesting introduction to both parts. In part one he discusses the use of the smallsword, but more relevant for us is the second part traite de l'espadron (treatise on the spadroon/saber)

According to de Saint Martin, the saber can be used against multiple opponents, cavalry against cavalry by the use of the moulinet including the coup de jarnac, que l'ennemi ne peut guere parer que par le plus grand hazard (which the enemy can hardly parry, only by the greatest coincidence). ${ }^{26}$

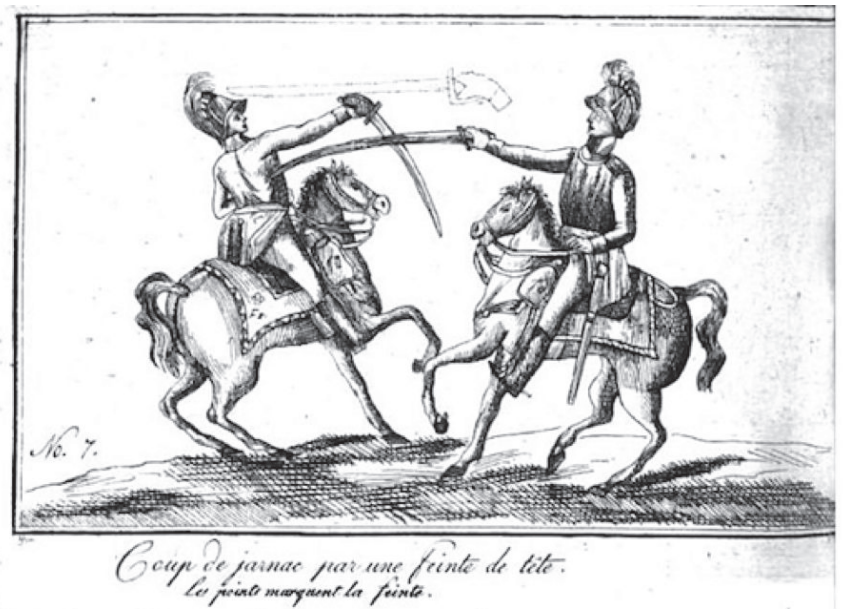

Figure 4 : de Saint Martin: $L$ 'art de faire des armes réduit à ses vrais principes, L'art de l'espadon (1804), plate 7. The coup de jarnac after a feint to the head.

\footnotetext{
24 de Saint Martin, L'art de faire des armes réduit à ses vrais principes, p. II.

${ }^{25}$ Ibid., pp. III and IX.

${ }^{26}$ Ibid., pp. IX-X.
} 
He also teaches how to use the saber against the bayonet and is against using sticks as training tools. ${ }^{27}$ It is interesting to see that after these brief general remarks, de Saint Martin offers a list of twenty rules - quite similar to the rules presented by Girard regarding respect in the salle d'armes: don't curse (rule 1), don't speak evil about those who are or are not in the room (rule 2), don't smoke or drink in the salle (rule 10), when one walks on the feet of another, one has to apologize (rule 16.), don't blow your nose too loudly (rule 17),...

After the section on the smallsword, section two starts, again with a brief introduction. De Saint Martin explicitly says that this section is meant for the cavalry, ${ }^{28}$ though he always makes a distinction between saber techniques on foot and on horseback. After a short praise of the Hungarian nation (for their brave spirit and military talents), he explains the intention of his section on the saber and then his lessons start...

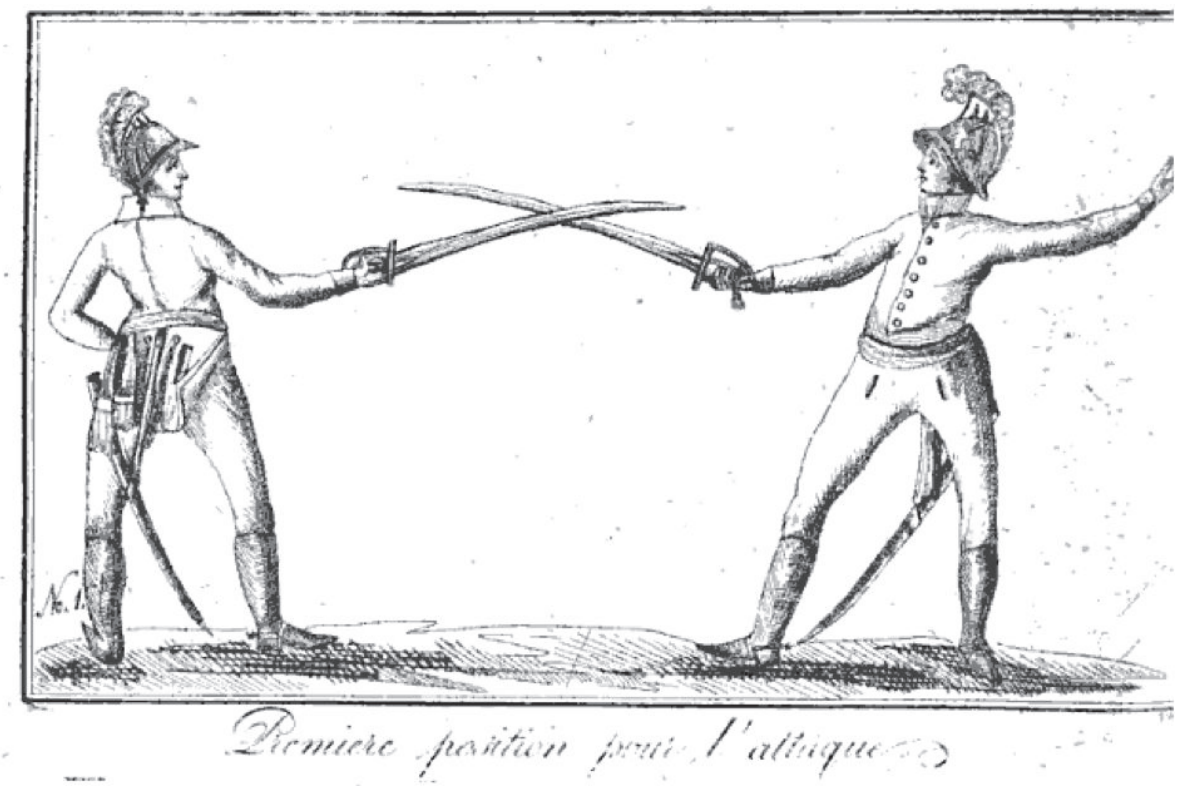

Figure 5: de Saint Martin: $L$ 'art de faire des armes réduit à ses vrais principes, L'art de l'espadon (1804), plate 1. In fencing on foot, the nails of the hand have to be bold upwards, on borse the nails have to be hold downwards.

De Saint Martin prefers the head and right arm as important targets (but other areas such as the belly are also targets) and strongly suggests the use of many feints.

\footnotetext{
27 Ibid., pp. XII.

28 de Saint Martin, L'art de faire des armes réduit à ses vrais principes, L'art de l'Espadon, p. II.
} 


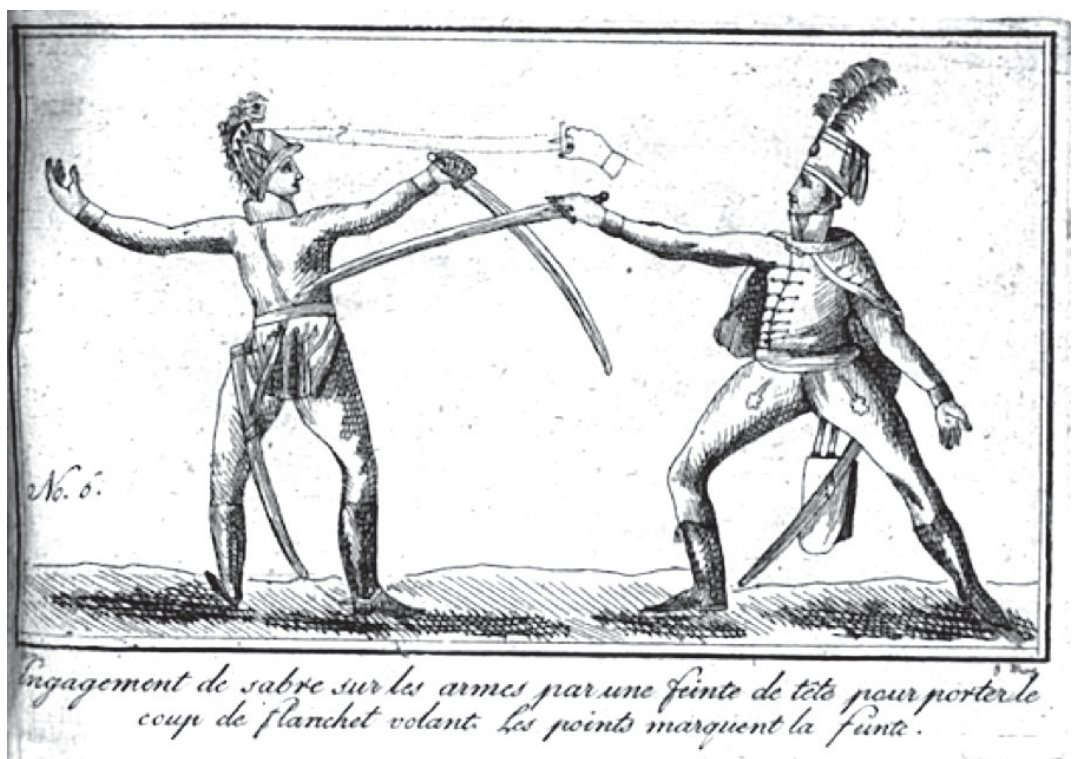

Figure 6 : de Saint Martin: $L$ 'art de faire des armes réduit à ses vrais principes, L'art de l'espadon (1804), plate 6.

Other advice he gives is not to hold the saber too firmly, because this makes the swordsman tired, ${ }^{29}$ it is also interesting to look the enemy in the eyes, to read the lines of his attack. ${ }^{30}$

De Saint Martin warns his readers about barbarians (Turks, Tartars and other people) with shorter and more curved swords who try to behead ther enemies. But because these people have to turn their saber to make it easier to cut off the head, they frequently miss their cut. ${ }^{31}$ Nevertheless, de Saint Martin also tells how to fight against these ferocious people.

\footnotetext{
${ }^{29}$ Ibid., p. 34.

${ }^{30}$ Ibid., p. 34.

${ }^{31}$ Ibid., p. 35.
} 


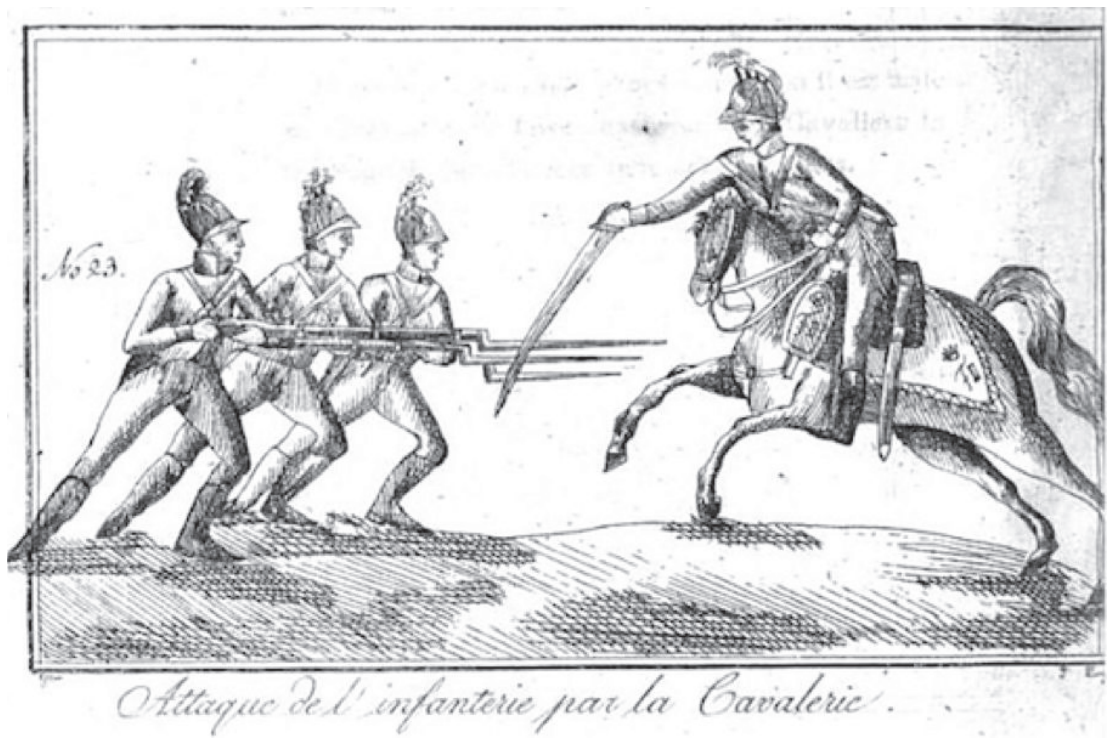

Figure 7 : de Saint Martin: $L$ 'art de faire des armes réduit à ses vrais principes, L'art de l'espadon (1804), plate 23.

Finally the work ends with some advice on (using the saber in) naval warfare and a violent attack against duels with the pistol: having the notion to duel with pistols can only arise in the head of a fool. Who would ever want to fight like this is nothing but a vicious animal. $^{32}$

\section{II.2.2. Alexandre Muller: Théorie sur l'escrime à cheval (1816)}

Not much information about the life of Alexandre Muller can be found. We know for sure that he served as captain under Marshall Claude-Victor Perrin (1764-1841) in the French cavalry and that he obtained a serious wound during his military career. At the end of the Empire he became instructor in Lunéville and later he worked in a military school in Saumur. In this school his task was to instruct other instructors for cavalry regiments. After following the lessons of Muller, these officers had to go back to their regiments to teach what they had learned from the school in Saumur.

Alexandre Muller wrote three treatises on the use of weapons: two on the use of the bayonet (Le maniement de la baïonette), published for the first time in 1815 and republished (and updated) in 1828, 1835 and $1845 .^{33}$

In 1816 he published his third treatise, this time dedicated to the use of the saber: Théorie sur l'escrime à cheval, pour se défendre avec avantage contre toute espèce d'arme blanches (Theory on

\footnotetext{
32 Ibid., pp. 53-54.

33 Muller, La baïonette et son maniement, pp. 2-3.
} 
mounted fencing to defend oneself with advantage against any kind of edged weapon.). This work was published with 51 images of very high quality and was an attempt to satisfy the need for good instructors after the terrible loss of many experienced French soldiers during to the war in Russia (1812). ${ }^{34}$

It is surprising to see that saber fencing is reduced to 'easy' principles without much theory, probably to make the instruction of saber fencing as efficient as possible. Muller only presents two guards: the quarte and the tierce and, in general, the instructions are very brief, easy to understand especially because of the clear images.
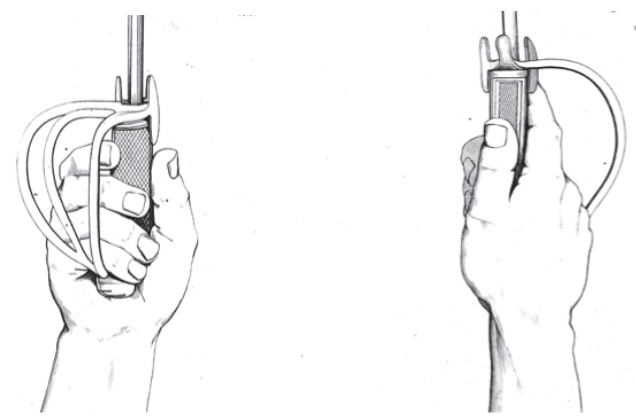

Figure 8 and 9 : Muller, Théorie sur l'escrime à cheval, pour se défendre avec avantage contre toute espèce d'arme blanches (1816), plate 3 and 4 . In the quarte the edge is turned towards the left shoulder or inwards; in the tierce the the edge is turned towards the right shoulder or outwards.

${ }^{34}$ Muller, Le sabre et l'escrime du cavalier, pp. 1 and 8. 


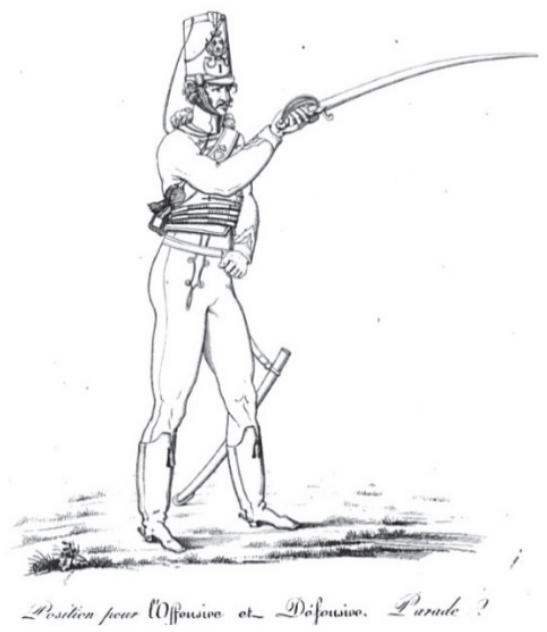

Figure 10 : Muller, Théorie sur l'escrime à cheval, pour se défendre avec avantage contre toute espèce d'arme blanches (1816), plate 8 .

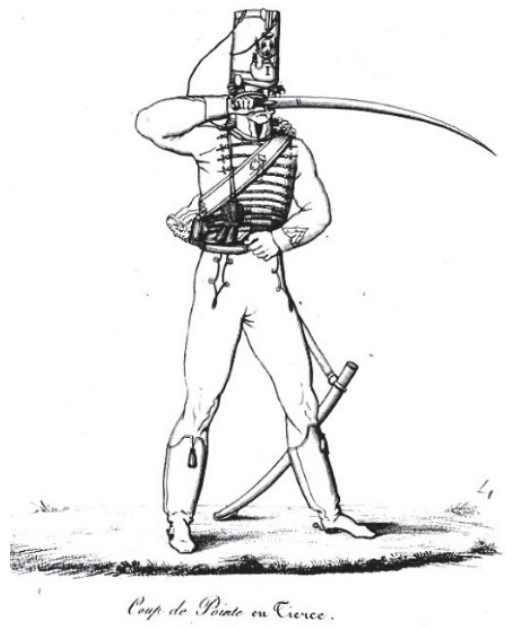

Figure 11 : Muller, Théorie sur l'escrime à cheval, pour se défendre avec avantage contre toute espèce d'arme blanches (1816), plate 11. 


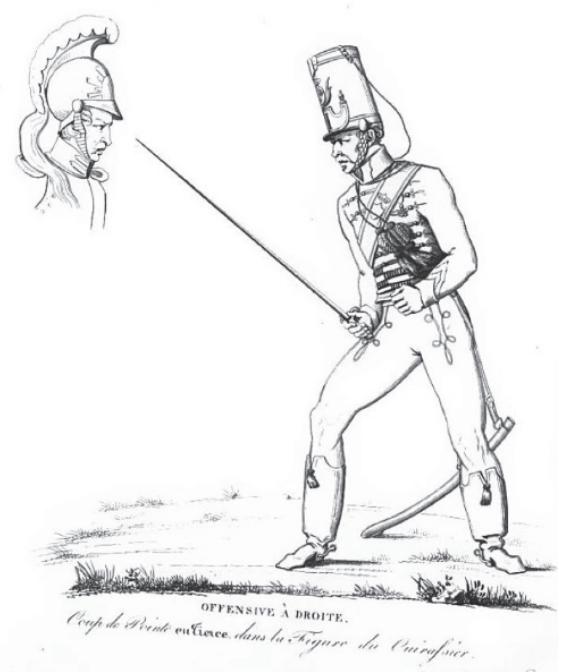

Figure 12 : Muller, Théorie sur l'escrime à cheval, pour se défendre avec avantage contre toute espèce d'arme blanches (1816), plate 28.

Muller gives instructions on how to fight with the saber against other sabers, but also against lances and bayonets. Generally, Muller advises to aim, as much as possible, at the face by cutting and by thrusting. This is certainly the case when one fights against cuirassiers who are better protected than other cavalry soldiers.

Hitting the reins of the horse is also advised by Muller, ${ }^{35}$ as Flemish carabinier Joseph Abbeel experienced in the battle of Borodino (7 September 1812):

After we had executed several charges on the cavalry of the enemy, I finally got wounded - at half past two in the afternoon - for the first time. In a charge on the dragoons of the Tsar, I moved myself a little bit to the side to make it easier for me to follow them. But one of them came to me and cut off the reins that I held in my hand. Without the leather of those bridles I would certainly have lost a thumb and a finger of my left hand. Immediately I took the watering rein [bridle strap used to bring the horse to a river and let it drink] in my bloody hand and I used my spurs. My attacker thought he could escape me, but he didn't get far because he didn't have a copper or iron jacket as we have, which could protect him against the thrust of my sword. After this was done, I returned to my regiment with my sword full of blood. When my lieutenant saw that I was wounded and that I could not use my reins anymore, he wanted to send me to the infirmary, but I told him that I

35 Ibid., pp. 28 and 34. 
was not seriously wounded and that I would soon be able to put my hands on another pair of reins. ${ }^{36}$

It is also interesting to note that Muller gives techniques to protect the head of the horse, because when a horse is hit on the head, the ranks of the cavalry can be disrupted, making it easier for the enemy to break them. ${ }^{37}$
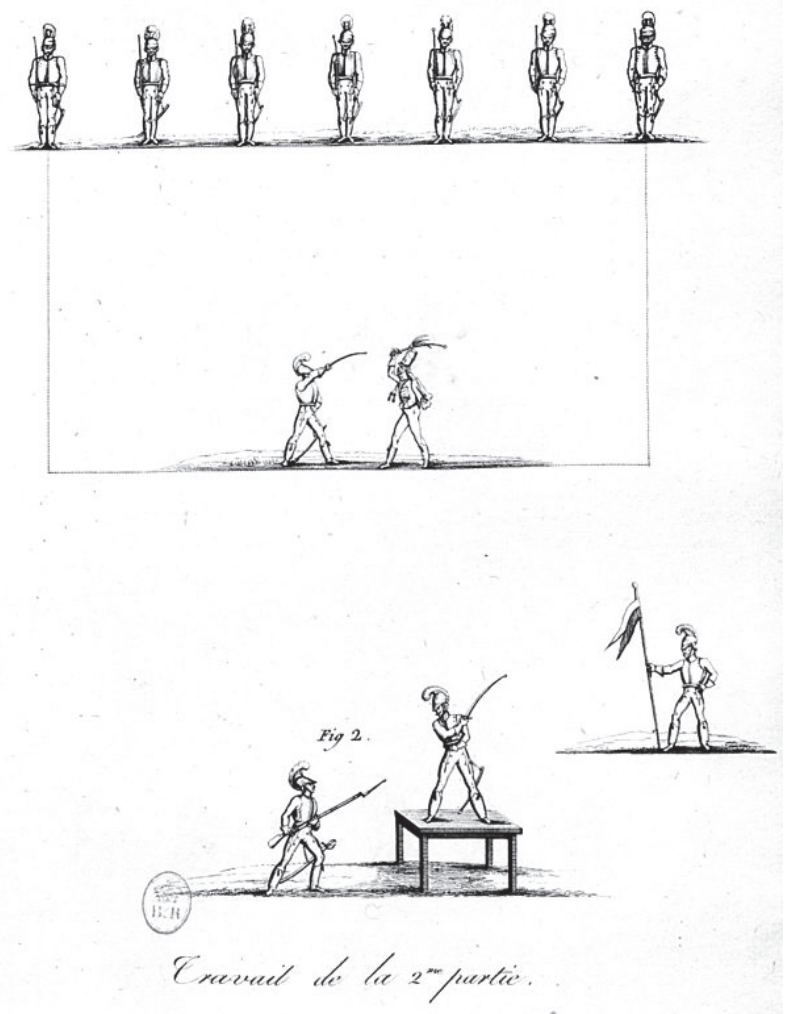

Figure 13: Muller, Théorie sur l'escrime à cheval, pour se défendre avec avantage contre toute espèce d'arme blanches (1816), plate 50.

It is interesting to see that Muller also sheds some light on how the instruction with the saber was done, here we can see small protective tips on the points of the sabers, lances and bayonet. The soldier on the table illustrates the case where a cavalry soldier is attacked by a bayonet from below.

\footnotetext{
${ }^{36}$ My translation from the original Dutch text: Abbeel, Met Napoleon naar Moskou, p. 78.

${ }^{37}$ Muller, Le sabre et l'escrime du cavalier, pp. 32-33.
} 


\section{II.2.3. Antoine Fortuné de Brack: Avant-postes de cavalerie légère' (1831)}

De Brack was a French officer who participated in several military campaigns with Napoleon and who obtained the Legion of Honor for his conduct in the battle of Wagram (5-6 July 1809). From 1807 until 1812 he was member of the $7^{\text {th }}$ Hussars and from 1812 till 1815 he served in the $2^{\text {nd }}$ Lancers of the Guard (the famous Red Lancers). After the defeat of Napoleon, he went to Brazil and returned to France in 1830. In 1831 he published his Avant-postes de cavalerie légère, translated into English by Major Lonsdale A. Hale and Captain F.T. Hobson as Light cavaly out-posts. This work, a real treasure trove on various kind of military subjects, was reprinted several times and was still in use during the Second World War ${ }^{38}$

His famous book is written in the Platonic tradition of question and answer, though it is certainly not a theoretical consideration on the art of war, because de Brack himself was a man of action who knew what he was writing about.

In the use of the saber, de Brack generally advises:

Thrust, thrust, as much as you can; you will throw to the ground all you touch; you will demoralize the enemy who has escaped your cuts, and you will add to these advantages that of never exposing yourself and being always on guard. In the first wars in Spain our dragoons achieved by their thrusts a reputation which demoralized the Spanish and English troops. ${ }^{39}$

In the Battle of Regensburg/Ratisbon (23 April 1809) the French cavalry confronted the Austrian cavalry and tried to wound as many of them by thrusting, while the Austrians put their confidence in the cut. This was certainly to the advantage of the French cuirassiers who were better protected by their cuirass which covered their front and backsides, while the Austrian cuirass only protected the front of the chest. ${ }^{40}$

Thrusting does not mean that a soldier has to omit cutting, "as a general rule only deliver cuts when the enemy is in front of or alongside you." 41

A swordsman should strike his opponent

at the level of the neck, because it is natural for a horseman attacked to lower his head, and thus you strike him in the face; if your blow fails, it hits the shoulder or forearm, and places him hors de combat. ${ }^{42}$

\footnotetext{
38 Roucaud, 'Etude des Avant-postes de cavalerie légère par le général de Brack', pp. 110-113.

${ }^{39}$ de Brack, Light cavalry out-posts, p. 51.

40 Op de Beeck, Napoleons nachtmerrie., p. 75.

41 de Brack, Light cavalry out-posts, p. 51.

${ }^{42}$ Ibid., p. 51.
} 
Further:

Every cutting edge is a saw, more or less fine, which produces its effect only by moving horizontally on the object it is used against. To produce this effect at the moment you strike, draw back the hand to the rear; therein lies the secret of the terrible sabre cuts of the Mamelukes. ${ }^{43}$

De Brack even writes about how to sharpen a sword (here he laments that soldiers don't take enough effort to sharpen their blades before combat), which file to use for this job, how to clean and dry the scabbard (and to put the sword gently in the scabbard, because otherwise you can cause edge damage!), how to avoid rust and even provides us with a very interesting anecdote:

Under the Empire, the cavalry did not carry a hatchet, and the sword was used instead of it, for purposes of the bivouac; the blade and edge consequently were soon in a bad condition; but the troopers, who understood their business, soon found a remedy for this unavoidable abuse of their weapon: 1st, by only using the lower part of the blade in cutting wood, pickets, etc. and thus keeping the upper part in good order for the fight; 2nd, by always carrying with them a small very soft file, with which they sharpened the blade when it had lost its edge. ${ }^{44}$

De Brack also critizes soldiers using their blades to roast meat, which is ruining the temper of the blade, nevertheless sergeant Bourgogne refers several times to this practice. ${ }^{45}$

De Brack concludes his section on the sword with the "General rule; take as much care of the blade of your sword as of the blade of your razor." 46

\section{II.2.4. F.C. Christmann (and G. Pfeffinger): Theoretisch-Praktische Anleitung des Hau und Stossfechtens (1838)}

To conclude this brief description of four valuable works concerning the use of the saber in the army of Napoleon, I have added the treatise of Christmann and Pfeffinger: Theoretisch-Praktische Anleitung des Hau und Stossfechtens und des Schwadronbauens nach einer ganz neuen Methode bearbeitet (Theoretical-practical instructions for fencing with cuts and thrusts and against multiple opponents according to a completely new method).

The only biographical information about Christmann can be found in the introduction of his book, written by Pfeffinger. Christmann was born in Germany (ein geborner Mainzer), professor in the art of fencing (professor der fechtkunst), member of the French fencing

\footnotetext{
43 Ibid., p. 52.

${ }^{44}$ Ibid., p. 53.

45 Bourgogne, Mémoires du sergent Bourgogne (1812-1813, ed. by Cottin and Hénault, pp. 63, 102, 108, 261 and 284.

${ }^{46}$ de Brack, Light cavalry out-posts, p. 55.
} 
academy in Boulogne and several other German academies. He fought in the Garde Impérial (the elite corps of Napoleon) and participated in many battles (viele Feldriuge..$^{47}$ Unfortunately this is the only information we have about the military career of Christmann. Pfeffinger also adds that Christmann has a lot of experience and taught his method to many students.

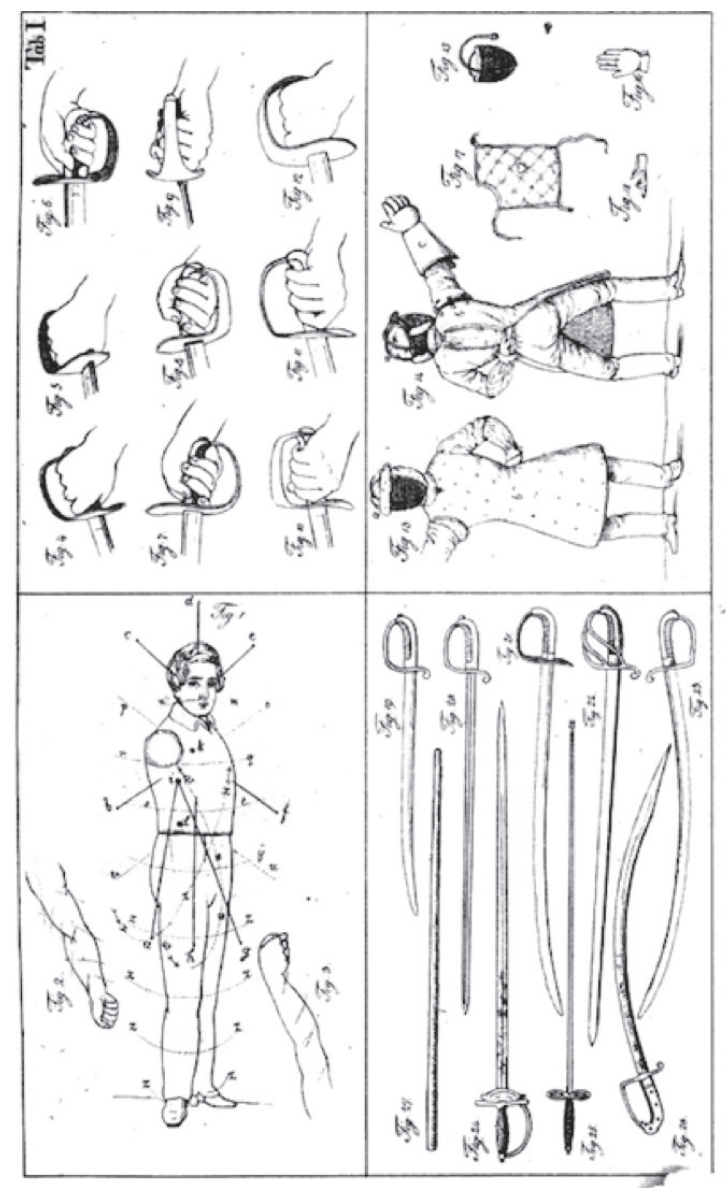

Figure 14: Christmann, Theoretisch-Praktische Anleitung des Hau und Stossfechtens (1838), plate 1.

Christmann gives a description of the different hilts, the protective gear, the target zones and also of the different kind of sabers.

47 Christmann and Pfeffinger, Theoretisch-Praktische Anleitung des Hau und Stossfechtens und des Schwadronhauens nach einer gan₹ neuen Methode bearbeitet, p. III. 
After studying from many masters, Christmann developped his own method (in collaboration with Pfeffinger) and according to Christopher Amberger, the centerpiece of this method is "the changing of the line of attack"

In the introduction to the book, Pfeffinger writes that their system is primarily meant for soldiers of the German army, ${ }^{49}$ whether they have to face one or multiple opponents. ${ }^{50}$ In the work of Christmann, we see different combat situations where the saber is facing other weapons such as the bayonet and even the lance of a mounted cavalryman. He also adds some interesting 'Bartitsu-like' situations where civilians, armed with sticks or unarmed, have to defend themselves against (un)armed ruffians.

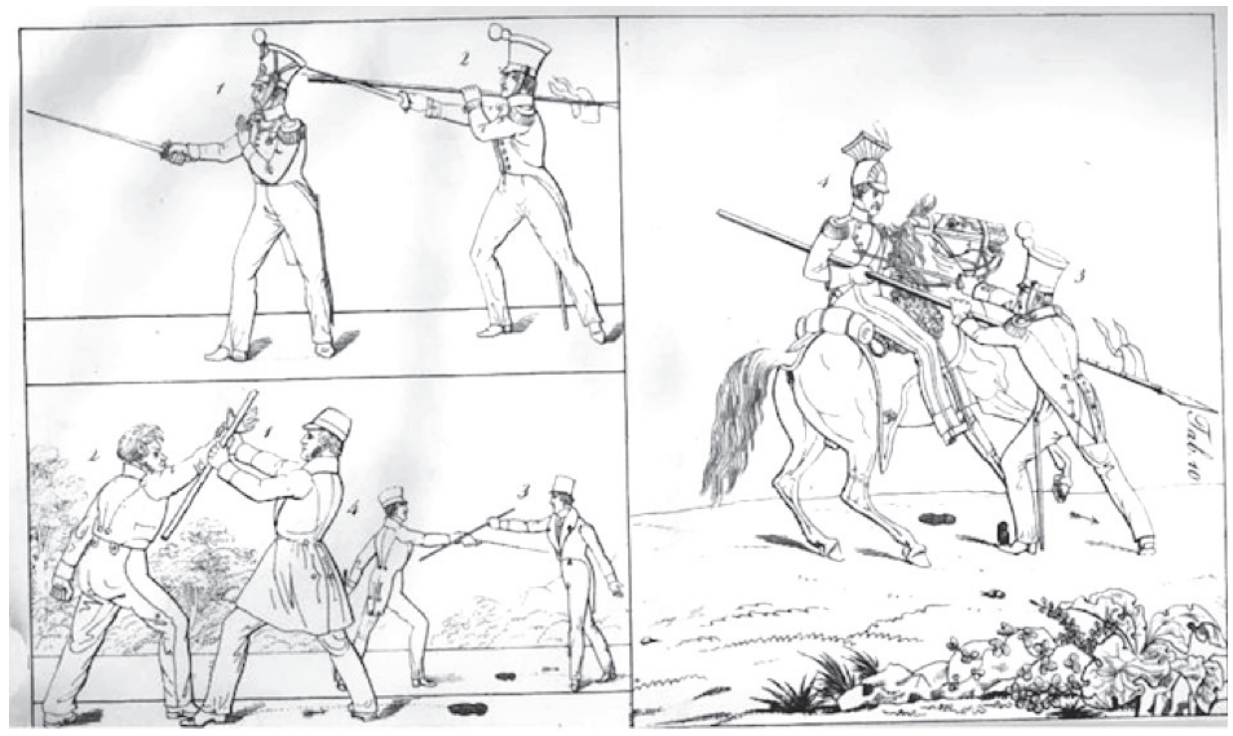

Figure 15: Christmann, Theoretisch-Praktische Anleitung des Hau und Stossfechtens (1838), plate 10.

48 Amberger, Saber fencing: Germany, 1838.

${ }^{49}$ Christmann and Pfeffinger, Theoretisch-Praktische Anleitung des Hau und Stossfechtens, p. V.

${ }^{50}$ Ibid., pp. V-VI. 


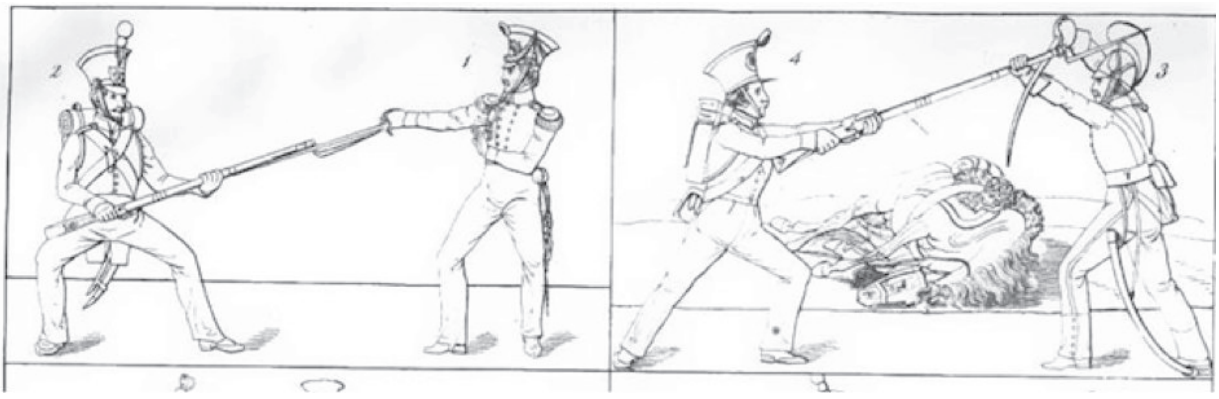

Figure 16: Christmann, Theoretisch-Praktische Anleitung des Hau und Stossfechtens (1838), plate 9.

The treatise of Christmann is not only written for combat, it also deals with the use of the saber as a a way of physical exercise. According to Christman, training with the saber is very helpful for young people to make them healthier and stronger. It takes away theirapathy to turn them in people who are proud on their nation and who have self confidence. ${ }^{51}$ These ideas about the physical advantage of training with the saber are elaborated on in the introduction. ${ }^{52}$ In this way, Christmann puts a huge emphasis on the sportive aspect of the saber. For people who only want to focus on the sportive aspect, it is possible to fence only with the so called 'legal' techniques, but Christmann adds that he has also included illegal techniques for the soldier who wishes to hit his opponent by all possible means. Of course it is possible for people who only want to use legal techniques to skip the illegal ones, however it is good to know both illegal and legal techniques. Further, Christmann gives advice for people who want to fence without protection to use only cuts and no thrusts. ${ }^{53}$

\footnotetext{
51 Ibid., pp. VII-IX.

52 Ibid., pp. 1-25.

53 Ibid., pp. 26-27.
} 


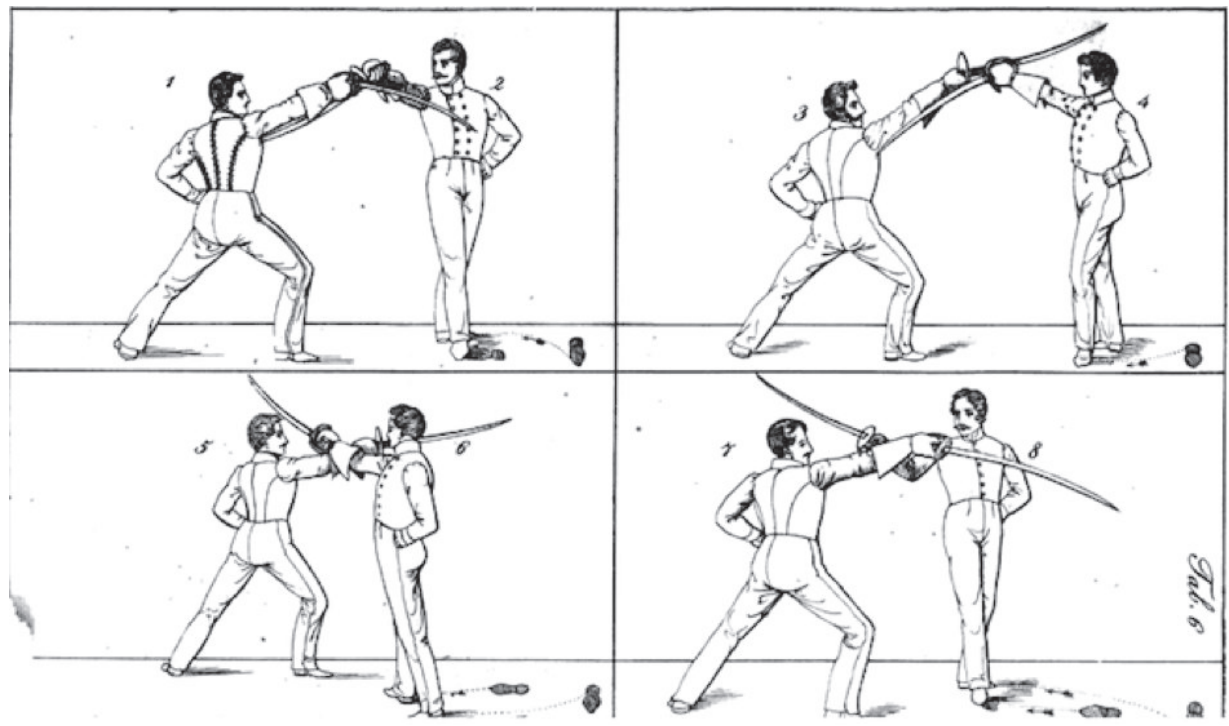

Figure 17: Christmann, Theoretisch-Praktische Anleitung des Hau und Stossfechtens (1838), plate 6.

After this second introduction, the reader still has to wait awhile beforelessons in the art of the saber begin. First he has to go through another theoretical part (Chapter 2) on the kind of sabers, the parts of the saber, protective gear, fencing with the stick, the position of the body, distance between fencers, target zones,... and even how to salute with the saber. After this introduction, the actual lessons start, which are remarkable because of their very systematical approach to fencing.

Without a doubt, Christmann's book is one of the most systematic and elaborate treatises on saber fencing, combining both the sportive and the martial aspect of fencing with the saber.

\section{II.3. Schools}

In Napoleonic France, students could go to several specialized military schools, such as the most prestigious Ecole Militaire Impériale de Saint-Cyr at Fontainebleau (Paris), where they learned horse riding, fencing, mathematics, military drawing, fortification, geography, history, military administration and human sciences. In another military school, the Prytanée Militaire in La Flèche (in the valley of the Loire) several masters were active in dancing, fencing, drawing, French grammar, German, English,... ${ }^{54}$

To become cavalry officer, Louis Rilliet went to the cavalry school of Saint Germain-enLaye (near Paris), where he studied for three to four years with about 600 students. The

${ }^{54}$ Histoire de la guerre d'Espagne contre Napoleon Buonaparte, tome I, pp. 96-97. 
teaching staff included four teachers of mathematics, four of history-geography, two teachers of literature, two of military administration,... and two fencing masters. ${ }^{55}$

\section{II.4. Masters-at-arms}

Most soldiers in the army of Napoleon, however, didn't go to military schools, but learned how to deal with edged weapons from their master-at-arms (maître d'armes). This was a soldier or lower officer who was skilled in the use of bladed weapons. Sometimes he was even known as fencing master (maître d'escrime) and assisted by provosts (prévot d'armes). He was the instructor at the regimental fencing school and could represent the regiment in tournaments against other units. He taught swordmanship and could even provide private lessons for an extra fee. Since the master-at-arms was not an official function in the army, Crowdy adds:

Perhaps the only formal instruction given to the master and his provosts was to withdraw lessons if the men became stormy and querulous rather than reserved and polite. ${ }^{56}$

It is not clear how frequent these lessons were and probably most of the soldiers learned how to deal with their sabers from the experience they obtained during military campaigns. Joseph Abbeel, who had some experience with horses in his homeland, became member of the carabiniers and is very brief in describing his military training. When he arrived in the military barracks of Lunéville (France) in September of 1806, he received his uniform and learned to walk in miltary parades on foot and on horseback. On the fourth day he was already challenged to a duel and though he had never had a saber in his hands, he didn't refuse the challenge. This was enough for his adversary who claimed he only wanted to test the bravery of Abbeel. In February 1807 (so after nearly three months of training) the carabineers had to leave to go on campaign, because they "now already had some experience in horseriding and using weapons". ${ }^{57}$ When he and his comrades arrived in Bad-Freienwalde (near Berlin) he received some more instruction and that is the last thing Abbeel writes about his training in the use of weapons.

\section{TYPES OF SABERS}

\section{III.1. Cavalry}

As mentioned before, the saber (or sword) was the ultimate weapon of the French cavalry during the Napoleonic wars, but they were also used by the infantry. (The French navy also made use of cutlasses, but because the French were never involved in close quarter

\footnotetext{
55 Rilliet, Journal d'un sous-lieutenant de cuirassiers, p. 6.

${ }^{56}$ Crowdy, Napoleon's infantry handbook, p. 48.

${ }^{57}$ My translation from the original Dutch text: Abbeel, Met Napoleon naar Moskou, p. 13.
} 
fighting and because the French navy during the Napoleonic era was not succesful, I have omitted the use of the cutlass in the French navy)

Many different types of cavalry sabers were used, but they can generally be divided into three groups: straight sabers (swords), slightly curved sabers and very curved sabers. The straighter the saber, the better it is for thrusting and the deadlier the wound. If needed, it can be used to cut with and it can also be used to hit an enemy who is situated at a lower position or even lying on the ground. Nevertheless, the thrust is more difficult to make than the cut and there is a risk of losing the sword in a thrust because it is difficult to withdraw it. ${ }^{58}$ Another risk is that the soldier damages his wrist, as De Brack mentions:

I have often seen troopers sprain their wrist, and be disabled for a whole campaing from having given a thrust awkwardly; it is easy to understand this, since they oppose only their fore arm to the whole force of the weight and speed of a mounted man. If they had drawn back the arm they would not have been hurt and would have been ready either to renew the attack or to return to the guard. ${ }^{9}$

In this way, the dragonne (lanyard or wrist strap) was very handy: a soldier could release his sword after the impact after it had done its deadly work, without actually losing the weapon. The straight blade was advised for the heavy cavalry (cuirassiers and carabiniers), while the lighter cavalry used the curved saber. ${ }^{60}$

58 Reinhard, The book of swords, p. 149.

59 de Brack, Light cavalry out-posts, p. 52.

${ }^{60}$ Haythornthwaite, Napoleonic cavalry, p. 28. 

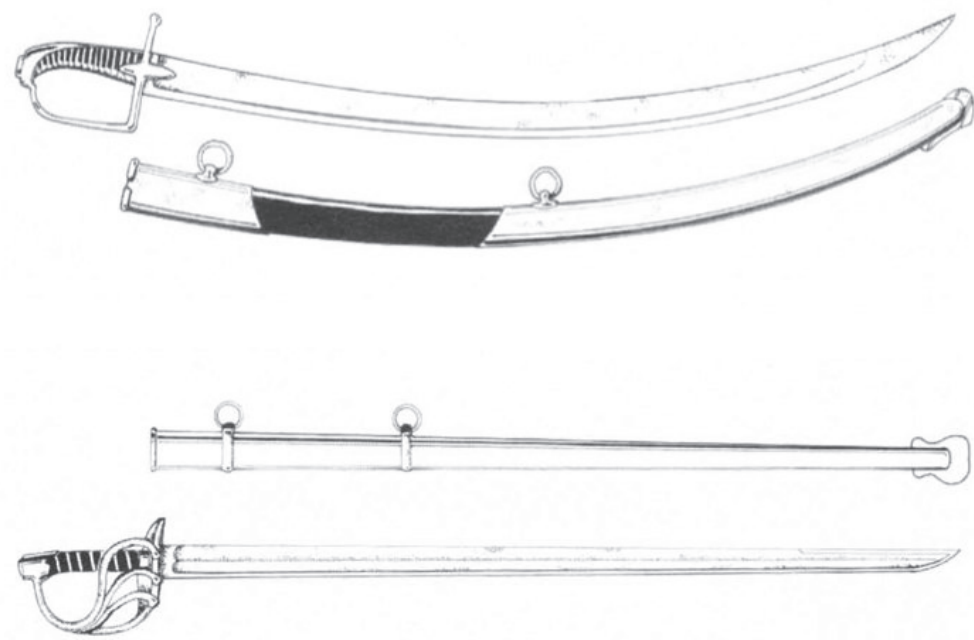

Figure 18: Above: An. IV pattern Hussar saber (model 1795-1796), which inspired the British 1788 light cavalry saber. Below: heavy cavalry saber (sword), an XIII pattern. Both of these weapons were carried in an iron scabbard. Haythornthwaite, Napoleonic cavalry, $p$.

31.

The curved blade was perhaps easier to use, and with some training it could also be used to thrust. On the other hand, and as illustrated by several examples further in this text, it was much easier to survive a cutting wound.

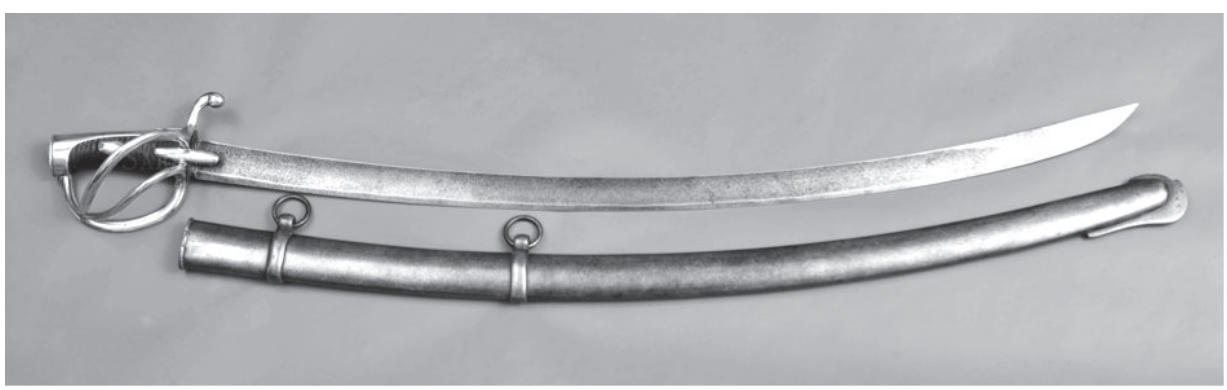

Figure 19: Light cavalry saber (An. XI-pattern, known as the 'chasseur-sabre') and iron scabbard, made at Klingenthal: this was the weapon of the light cavaly, Hussars, Lancers, Chasseurs à Cheval. This saber has a weight of 1,21 kg (the scabbard weights about $1,3 \mathrm{~kg}$ ) and a blade of $87 \mathrm{~cm}$.

Source: http:/ / swordscollection.blogspot.com.ar (accessed 5 May 2015).

Reproduced with permission of the owner. 
Most cavalry blades were kept in iron scabbards, which had a bad influence on the sharpness of the edge and could even cause rusting. On the other hand: leather scabbards were too expensive to make and less sturdy. ${ }^{61}$

Probably most edges were not sharp enough to cut off limbs as a whole and they were certainly not razor sharp. Still, they could have a terrible power, as sergeant Bourgogne tells about his sergeant-major who was involved in a duel and whose head was cut from front to chin. ${ }^{62}$

Cutting off heads (and other body parts) was the the "speciality" of Mamelukes as Dominique Larrey described in his writings (see below) and which is also recorded in other texts. When French soldier Jean-Roch Coignet participated in the Battle of Austerlitz (2 December 1805), he also saw the devastating power of the curved saber of the 48 mamelukes who were involved in the battle

These mamelukes are excellent horsemen, they can do with their horses whatever they want. With their curved saber, they can cut off a head in just one blow, and with their sharp stirrups they cut the flanks of soldiers. ${ }^{63}$

Though the Mamelukes in the Battle of Austerlitz served under the French flag, they originally were fearsome enemies of the French when they fought them in the Egyptian campaign of Napoleon (1798-1799). The French were so impressed by them, that they made them a small but impressive part of their army. They never actually numbered more than 150 soldiers, though later even Europeans could become member of their regiment, so their numbers increased. The French admired the flamboyant clothing of the mamelukes, their bravery in battle and imitated the Mameluke way of oriental clothing and... sabers. ${ }^{64}$

\footnotetext{
61 Ibid., p. 28.

${ }^{62}$ Bourgogne, Mémoires du sergent Bourgogne, p. 334.

${ }^{63}$ Ces mamelucks étaient de merveilleux cavaliers; ils faisaient de leur cheval ce qu'ils voulaient. Avec leur sabre recourbé, ils enlevaient une tête d'un seul coup, et avec leurs étriers tranchants ils coupaient les reins d'un soldat. Coignet, Les cabiers du capitaine Coignet (1799-1815), ed. by Larchey, p. 473.

${ }^{64}$ Pawly and Courcelle, Napoleon's mamelukes, pp. p. 8-9 and 15-16.
} 


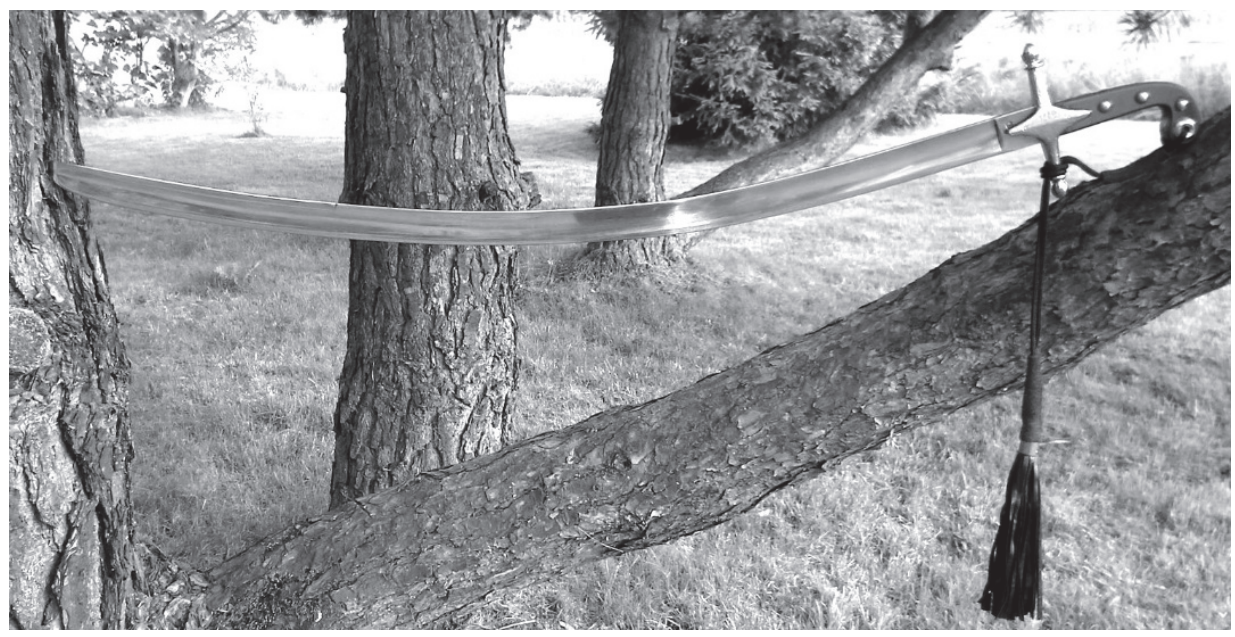

Figure 20: Reconstruction of French Mameluke Saber, made by Miran Krsticic. Reproduced with permission of the owner.

\section{III.2. Infantry: grenadiers and officers}

Even the infantry of Napoleon's army carried sabers (called a briquet), in the beginning it was worn by all grenadiers and light infantry, but later it was limited to sub-officers, grenadiers, carabineers and rummers by the imperial decree of 7 October 1807 . The weapon was $75 \mathrm{~cm}$ long, including $15 \mathrm{~cm}$ for the hilt. ${ }^{65}$ Similar to the cavalry sabers the briquet was also decorated with a dragonne.

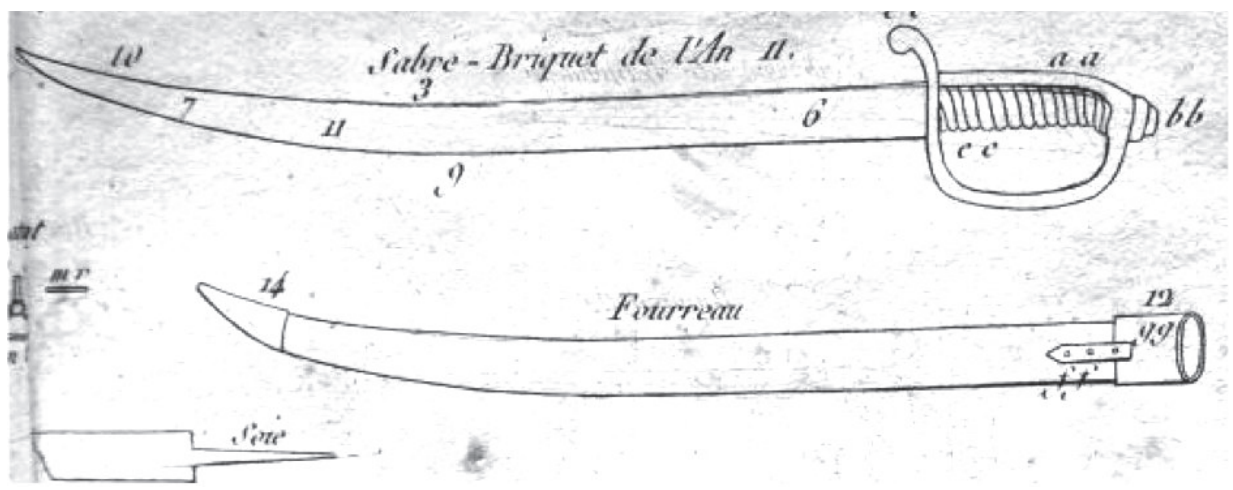

Figure 21: The rounded hand guard made the saber very similar to a tinder striker, bence it was mockingly called 'briquet' (a sort of metal blade to strike against flints to make fire).

Crowdy, Napoleon's infantry handbook, p. 101.

${ }^{65}$ Crowdy, Napoleon's infantry handbook, p. 101. 
A special saber was carried by the sappers (sapeur d'infanterie) who specialized in performing assault demolitions. They were usually much stronger than the common infantrymen and also wore special uniforms (e.g. a leather apron). They were equipped with an axe, heavy gauntlets and a sawtooth saber. ${ }^{66}$

The usual weapon for infantry officers was the spontoon (or espontoon). In regulations from 1779, one can read that this weapon had a blade of about $70 \mathrm{~cm}$, not meant for cutting or parrying but mainly for thrusting. From 1790 onwards, the saber became more popular, probably because the officers wanted to imitate the light cavalry officers. ${ }^{67}$

\section{DUELLING IN THE FRENCH ARMY}

Officially, duelling was not permitted in the French army, but in reality it was also not really forbidden and even extremely popular. In 1792 an edict stated that it was forbidden to draw swords within the walls of a fortress, so actually it was acceptable to fight outside of the walls of the garrison or encampment. ${ }^{68}$ The example of the $5^{\text {th }}$ Hussars regiment clearly shows why the army staff didn't encourage duelling: in this regiment about eleven soldiers and sub officers died as a result of duelling between 1793 and 1810, in the period between 1796 and 1813 duelling wounds caused 19 soldiers and sub officers to be unable to perform their duties. ${ }^{69}$ Nevertheless, and in spite of strong moral condemnations against duelling (as by Barrère in the Moniteur 183 of 2 July 1791), duelling wasn't even mentioned in the French national law and there was certainly no specific law against it. ${ }^{70}$ According to Cohen "courts tended to act only when a fatality resulted from a breach of established etiquette." 71

Duels between soldiers indeed had certain rules of etiquette: after an official challenge, the details were arranged between the offended parties with the assistance of 'seconds'. These seconds agreed on time and place and they could even act as mediators when one of the parties wanted a way of reconciliation. It was also the seconds who determined the choice of weapons: pistols or sabers. The choice for pistols was usually influenced by an injury to one or both of the duellists, which caused him not to be able to fight with an edged weapon (so he had to choose a distance weapon such as the pistol). ${ }^{72}$ Usually duellists fought naked to the waist (or with open shirt), so they were unable to wear hidden

\footnotetext{
${ }^{66}$ Ibid., p. 47.

${ }^{67}$ Ibid., p. 102.

${ }^{68}$ Ibid., p. 155.

${ }^{69}$ Massoni, Histoire d'un régiment de cavalerie légère, p. 229.

${ }^{70}$ Briost, Drévillon and Serna, Croiser le fer, pp. 462-463.

${ }^{71}$ Cohen, By the sword, p. 97.

72 Crowdy, Napoleon's infantry handbook, p. 155.
} 
protective mail under their shirts. This mail was sometimes even coloured in flesh colour (called supersticerie), to hide it even better. ${ }^{73}$

A fine example of etiquette between duellists can be found in the memoires of captain Parquin (1786-1845) who was involved in a duel with smallswords: his first thrust was deflected by the buckle of the suspenders of Malet, his opponent, and made him bleed slightly. For Parquin's opponent, this was not a real wound, so he wanted to continue the fight. After several exchanges and driving back his adversary, Parquin managed to give him a thrust in the right side, which caused Malet to fall down. Immediately Parquin ran to Malet to help him and even asked his own seconds to help his brave adversary. Together they brought Malet to the army surgeon who told them that the wounded Malet was going to survive his wound without any problem. ${ }^{74}$

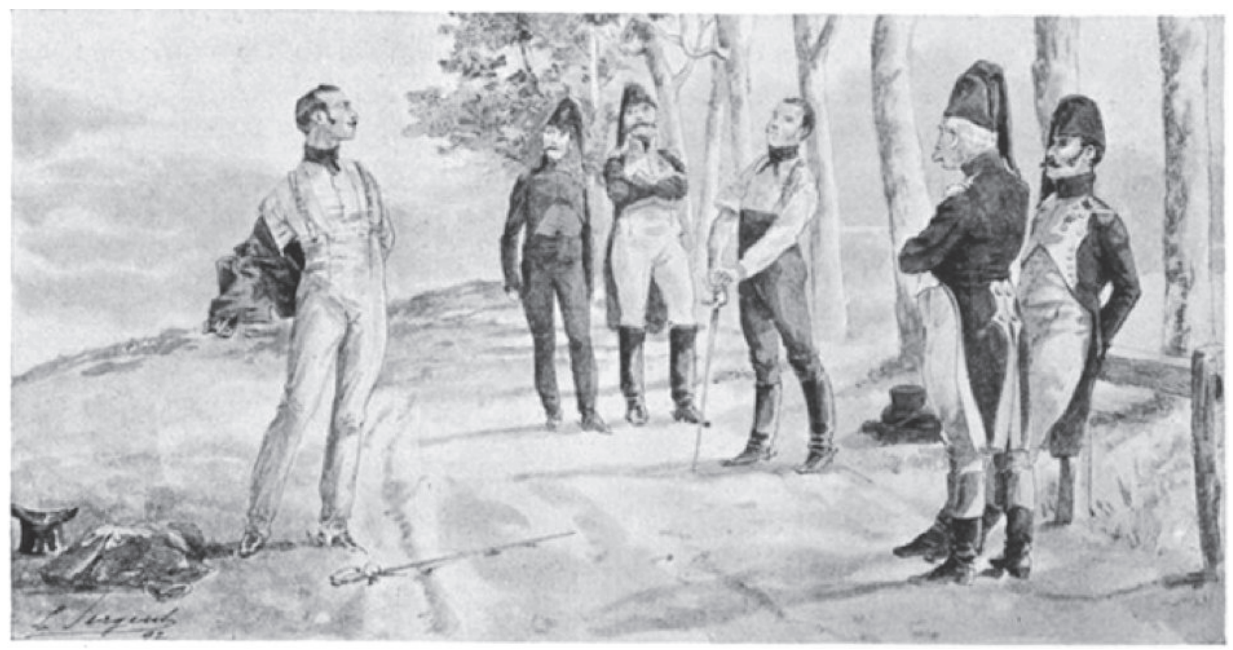

Figure 22: Parquin and Malet are about to duel.

Parquin, Récits de guerre ([1842], 1892), p. 107.

Dominique Larrey (see below) mentions several cases of soldiers whom he treated after they had fought in duels. One soldier had his forearm amputated because Larrey feared the soldier would get infected with gangrene. ${ }^{75}$ In one case Larrey dedicated several pages to describe the treatment and healing process of the arm wound of Pierre Cadrieux, who was injured in a duel. Not one bad word is said about the origin of the wound, Larrey

\footnotetext{
73 Cohen, By the sword, p. 97.

74 Parquin, Récits de guerre: Souvenirs du capitaine Parquin, pp. 106-108.

${ }^{75}$ Larrey, Mémoires de chirurgie militaire et campagnes, p. 455.
} 
seems very enthusiastic to describe the complex arm wound and how he could heal it, it is even used as an interesting case in the Medical School of Paris. ${ }^{76}$

Several French officers had a history of duelling: Pierre Augereau (1757-1816), son of a Parisian fruit-seller, fencing master, officer of Napoleon who started as a common soldier was a famous duellist. He had the reputation of a champion swordsman and had to flee the army after killing an officer in a quarrel. During this travelling life, he worked as a fencing master and even taught dancing, until he returned to the army in 1792 when deserters received amnesty from the government. In the army of Napoleon, he became a famous commander, known for his bravery and meticulous clothing and apperance. ${ }^{77}$

The most famous duel between two Frenchmen during the Napoleontic era was the duel between Fournier Sarlovèze (1773-1827) and an officer named Dupont. Sarlovèze was known as the "demon of the Grande Armée" and loved challenging civilians to duel with him, but he became legendary because of a long series of duels which lasted from 1794 to 1813. Finally, Dupont wanted to stop this stupid behaviour - he was about to marryand challenged Fournier to a pistol duel. Fournier wasted his two shots and was delivered to the mercy of Dupont who still had two bullets left which made Fournier eternally in debt to Dupont and thus a long series of duelling (lasting almost 20 years) was ended. ${ }^{78}$

The story of the duel between these two men was the source of inspiration for Joseph Conrad's story The Duel, which was the basis of the movie by Ridley Scott, The Duellists (1977).

\section{INDIVIDUAL MARTIAL PROWESS ON THE BATTLEFIELD}

Stories about individual swordsmen are the most fascinating ones and in this chapter I will briefly present some spectacular stories of individual sword or saber wielding bravery on the battelfield. The power of the cavalry lay in its massed force of thousands of armed men, augmented by the speed and weight of their horses, which made them into a huge and heavy hammer designed to smash the enemy, as the most famous cavalry charge of the army of Napoleon demonstrated at Eylau (7-8 February 1807). Here the cavalry of Murat sabred down the Russian artillery and made a difficult battle into a questionable and bloody French victory.

Nevertheless, there are several stories of individual martial bravery and skill. Sometimes individual soldiers even challenged their enemies to a personal duel in the empty space between the opposing lines of battle. ${ }^{79}$

\footnotetext{
${ }^{76}$ Ibid., pp. 896-901.

${ }^{77}$ Haythornthwait; and Courcelle, Napoleon's commanders, pp. 10-11.

${ }^{78}$ Elting, Swords around a throne: Napoleon's Grande Armée, pp. 174 and 694.

${ }^{79}$ Ibid., p. 602.
} 


\section{V.1. Jean-Louis Michel (1785-1865)}

The best swordsman ever in the army of Napoleon was without doubt the mulatto JeanLouis Michel (1785-1865), who was born in Haiti and came to France in 1796 as un pupille de régiment. Only eleven years old, probably a war orphan, looking fragile, he learned to fence from the fencing master of the regiment, the Flemishman M. d'Erape. His talents were soon discovered and soon Jean-Louis was known for his omitting of everything in fencing that he saw as superfluous: saluting, contre-coups, pauses,... In 1804 he was insulted for being a mulatto swordsmen and Jean-Louis was forced to duel. His opponent could use a normal sword, but Jean-Louis preferred a buttoned foil by which he gave his opponent a terrible punishment. He smashed him so hard in the face that he was knocked over and left bleeding on the floor. But his greatest achievement had yet to come. In 1812 the Italians who were fighting under Napoleon in Spain, refused to support their French colleagues and started to fight against them. It didn't take long for the first victims to fall, so the officers had to find a solution: it was decided that fifteen fencing masters and provosts from the Italians and Frenchmen had to fight in succession until only one regiment didn't have any man left. The two quarrelling teams went outside Madrid and some thousand men (and their families) watched the 30 people fighting for their lives. Jean-Louis fought on the French side against his first opponent, the Italian Giacomo Ferari, a tall man with a lot of combat experience. Jean-Louis defeated him without any problem, waited two minutes for the next opponent and kept on fighting until someone would injure him fatally... but that was not so easy. No less than 13 Italians were dead or seriously wounded and Jean-Louis was still standing. Though he was also bleeding, he wanted to defeat the last two Italians, who were full of fear. Then it was decided to stop the fight and the army shouted "Vive Jean-Louis!" "Vive le 32ième" (the regiment of the French)! Vive le 1er (the regiment of the Italians)! Jean-Louis shouted back: "We are all one and the same family. Vive l'Armée!" Jean-Louis retired to Metz, where he opened a fencing school, which later moved to Montpellier. Until his death, and even blind - so he had to do everything by touch- Jean-Louis kept on teaching. ${ }^{80}$

\section{V.2. Jean-Baptiste Guindey/Guindet (1785-1813)}

One of the most famous stories about martial skill, mentioned in several Napoleonic memoirs, is told about sergeant Jean-Baptiste Guindey/Guindet (1785-1813), quartermaster of the 10th Hussars. During the Battle of Saalfeld (10 October 1806) Guindey was confronted with the Prussian prince Louis (Lewis) Ferdinand. Baron de Marbot (1782-1854) gives us a detailled description of the fight:

Prince Lewis might yet have fallen back on the Prussian force which was occupying Jena, but having been the prime instigator of the war it seemed to him unseemly to retire without fighting. He was cruelly punished for his temerity. Marshal Lannes, cleverly taking advantage of

${ }^{80}$ Cohen, By the sword, pp. 97-99. 
the high ground under which Prince Lewis had so imprudently deployed his troops, first played upon them with artillery, and when they were shaken sent forward his masses of infantry, who, rapidly descending from the high ground, poured like a torrent on the Prussian battalions and broke them up in a moment. Prince Lewis, losing his head, and probably seeing the mistake he had made, tried to repair it by putting himself at the head of his cavalry, with which he impetuously charged the 9th and 10th Hussars. At first he gained a slight advantage, but our hussars, returning to the charge with fury, threw back the Prussian cavalry into the marshes, their infantry at the same time flying in confusion before ours. In the middle of the scuffle Prince Lewis found himself engaged hand-to-hand with a sergeant of the 10th Hussars, named Guindet. Being summoned to surrender, he answered with a sword-stroke which laid open the Frenchman's face, whereupon the other ran the prince through the body, killing him on the spot. ${ }^{81}$

Even de Brack mentions this fight:

As soon as you have delivered the thrust, if the enemy does not surrender, deal him a backhanded blow; it was thus that Guindet killed the Prince of Prussia at Saalfield. ${ }^{82}$

For his action Guindey received the cross of honour, though Napoleon regretted that the prince was not taken alive. When Guindey heard about this - he was in the hospital when Napoleon uttered his regrets - he replied that Louis-Ferdinand was not really in the mood to surrender...83 Unfortunately, Guindey lost his own life in the Battle of Hanau (20 October 1813): his body was entirely covered with saber wounds and he was surrounded by several dead Bavarian horsemen, whom he made pay terribly for his death. ${ }^{84}$

\footnotetext{
81 de Marbot, The memoirs of Baron de Late, ed. by Butler, p. 178.

82 de Brack, Light cavalry out-posts, p. 52.

83 Parquin, Récits de guerre, p. 45.

${ }^{84}$ Ibid., p. 142.
} 


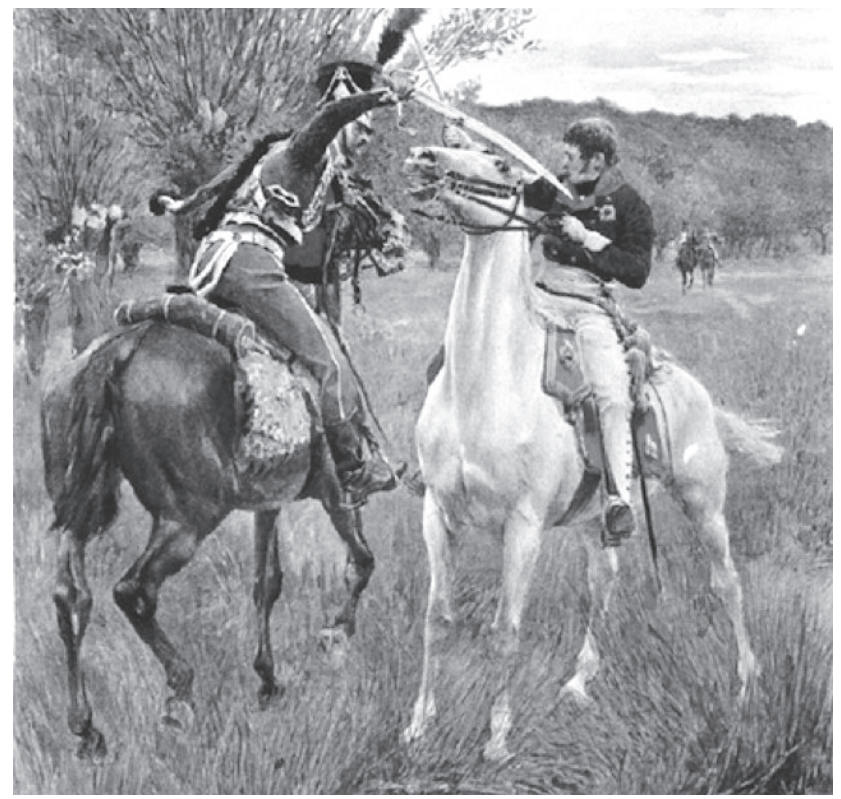

Figure 23: The fatal duel between Louis-Ferdinand and Guindey

Parquin, Récits de guerre ([1842], 1892), plate 4.

\section{V.3. Jean Baptiste Antoine Marcellin de Marbot (1782-1854)}

Marbot, who provided us the story of Guindey, was also involved in a very serious saber fight, when he was fighting in Spain (1811) under general Masséna.

So, being sure that the orders had been conveyed, I was about to return, when a young English light infantry officer trotted up on his pony, crying, 'Stop, Mr. Frenchman; I should like to have a little fight with you!' I saw no need to reply to this bluster, and was making my way towards our outposts, 500 yards in arrear, while the Englishman followed me, heaping insults on me. At first I took no notice, but presently he called out, 'I can see by your uniform that you are on the staff of a marshal, and I will put in the London papers that the sight of me was enough to frighten away one of Massena's or Ney's cowardly aides-de-camp!' I admit that it was a serious error on my part, but I could no longer endure this impudent challenge coolly, so, drawing my sword, I dashed furiously at my adversary. But just as I was about to meet him, I heard a rustling in the wood, and out came two English hussars, galloping to cut off my retreat. I was caught in a trap, and understood that only a most energetic defence could save me from the disgrace of being taken prisoner, through my own fault, in sight of the whole French army, which was witness to this unequal combat. So I 
flew upon the English officer; we met; he gave me a slash across the face, I ran my sword into his throat. His blood spurted over me, and the wretch fell from his horse to the ground, which he bit in his rage. Meanwhile, the two hussars were hitting me all over, chiefly on the head. In a few seconds my shako, my wallet, and my pelisse were in strips, though I was not myself wounded by any of their blows. At length, however, the elder of the two hussars, a grizzled old soldier, let me have more than an inch of his point in my right side. I replied with a vigorous backhander; my blade struck his teeth and passed between his jaws, as he was in the act of shouting, slitting his mouth to the ears. He made off promptly, to my lively satisfaction for he was by far the braver and more energetic of the two. When the younger man found himself left alone with me, he hesitated for a moment, because as our horses' heads were touching, he saw that to turn his back to me was to expose himself to be hit. However, on seeing several soldiers coming to my aid, he made up his mind, but he did not escape the dreaded wound, for in my anger I pursued him for some paces and gave him a thrust in the shoulder, which quickened his speed. During this fight, which lasted less time than it has taken to tell it, our scouts had come up quickly to set me free, and on the other side the English soldiers had marched towards the place where their officer had fallen. The two groups were firing at each other, and I was very near getting in the way of the bullets from both sides. But my brother and Ligniville, who had seen me engaged with the English officer and his two men, had hastened up to me, and I was badly in want of their help, for I was losing so much blood from the wound in my side that was growing faint, and I could not have stayed on my horse if they had not held me up. As soon as I rejoined the staff, Masséna said, taking my hand, 'Well done; rather too well done! A field officer has no business to expose himself in fighting at the outposts.' The wound in my cheek was not important; in a month's time it had healed over, and you can scarcely see the mark of it along my left whisker. ${ }^{85}$

\section{V.4. Grenadier Hennin (died 1805)}

Marbot managed to defeat three cavalry men in one fight, but what about grenadier Hennin, who killed seven Austrians with his saber in the Battle of Ulm (16-19 October 1805) as recorded by Nicolas Devout (1770-1823) in one of his letters to marshal Berthier (1753-1815). Hennin, who was fighting in the $108^{\text {th }}$ line, was standing in the middle of an Austrian troop of soldiers and tried to grab their flag. His own musket was broken so only his saber was left to fight with. With success, he killed seven enemies and maybe he

${ }^{85}$ Marbot, The memoirs of Baron de Late, II, pp. 146-147. 
could have killed more but his weapon broke and he was killed... Davout adds: cette mort est digne d'un grenadier français (this death is suitable for a French grenadier). ${ }^{86}$

\section{V.5. Leaulteur}

Sometimes the name of the individual swordsman is lost, as is the case of an anonymous French officer (or is he called M. Lealteur?) who defended the emperor the day after the Battle of Maloyaroslavets (24 October 1812). Sergeant Bourgogne records how this officer was defending Napoleon when he was surrounded by cossacks. Using his saber, the Frenchman killed one Cossack and wounded several of them but lost his weapon and military hat. Because he didn't have any weapon left, he took a lance of the enemy and kept on fighting. A grenadier à cheval saw what was happening and took his comrade for a Russian and pierced him with his saber. The grenadier realized what he had done and wanted to kill himself by taking as many enemies with him as possible, but didn't succeed. Now he became a hero and killed many of them with his saber. He was covered with blood and when there was no enemy left he went to his own men to ask about the officer he wounded. Luckily the officer survived his wound and could return to France. ${ }^{87}$

\section{V.6. Marie-Thérèse Figueur (1774-1861)}

Most of the deeds of arms were performed by men, but sometimes remarkable women appear. One of them was Mademoiselle Marie-Thérèse Figueur (1774-1861), also known as Madame Sans-Gêne (the lady without shame), who served as a women dragoon in the army of Napoleon. She dictated her memories to a certain Saint Germain, so we are well - but maybe not neutrally- informed about her life. When she was soldier in the revolutionary Army of the Eastern Pyrenees, she had to flee the enemy and rallied her comrades to follow her. Suddenly someone pointed a gun at her, but Madame Sans-Gêne was not afraid: she rushed to her opponent and hit him in the throat with her saber, in her words: c'est ce qu'en langage militaire nous appelons le coup du cochon (this is what we call in military language: the cut of the pig88). Marie-Thérèse didn't even notice that his bullet hit her helmet and messed up her hair on the left side. Later, in a battle against the Austrians (1799: Battle of Savigliano), she received four sword blows on her back, but she was only lightly wounded. When she was taken away as prisoner, some farmers tried to take off her wet boots and this caused her, in combination with the four wounds on her back, the most terrible pain of her entire life: "it was as if the ruffian was skinning my legs". ${ }^{89}$

During her career, several of her horses were shot from under her and she was also taken prisoner, twice by Austrian and twice by Spanish soldiers.

\footnotetext{
86 Davout, Le Maréchal Davout, Prince d'Eckmühl, ed. by d'Eckmühl de Blocqueville, pp. 70-71.

${ }^{87}$ Bourgogne, Mémoires du sergent Bourgogne, pp. 59-60.

${ }^{88}$ Figueur, Les campagnes de mademoiselle Thérèse Figueur, aujourd'hui Madame Veuve Sutter, p. 63.

${ }^{89}$ Ibid., p. 96.
} 


\section{V.7. Madeleine Kintelberger}

The last example of martial prowess is a truly exceptional story but almost forgotten in history. In 1805 a detachment of the French Seventh Hussar Regiment was attacked by a much larger group of Russian soldiers and was about to collapse. One of the fighters was Madeleine Kintelberger who lost her husband Joseph Kintelberger in the fight and who was now hopelessly trying to protect her six children. While her children were sheltering behind the ammuniton of the regiment, her husband dying in front of her eyes after he was struck by a cannon ball, and being pregnant for about six months, Madeleine was also hit by a cannon ball which almost tore away her right arm below the shoulder. Nevertheless Madeleine took up a sword, wielded it expertly and fought off several mounted attackers. Meanwhile she was bleeding from her arm and got injured again by saber cuts and lance wounds. The cossacks wanted to take this exceptional woman alive and shot her in the leg, but this didn't stop the brave lady from fighting, so they shot her in the other leg. Then the cossacks captured her and her wounded children and escaped from the battelfield. In captivity her arm was amputated, her other thirteen wounds were taken care of and, in prison, she gave birth to a twin. In 1806 she could return to her homeland, because of the temporary peace between France and Russia. General Jean Rapp provided a luxury coach to transport Madeleine and her children back to France where she received an extraordinary pension by Napoleon himelf, who never saw such an act of bravery. ${ }^{90}$ Thomas Cardoza, who writes about this story, adds:

Nevertheless, despite her almost unbelievable courage and suffering, today Madeleine Kintelberger is totally forgotten. She appears in no history books, no monument reminds us of her deeds, and even in her own country she remains completely unknown. ${ }^{91}$

\section{WOUNDS CAUSED BY THE SABER}

\section{VI.1. Introduction}

Soldiers and officers in the army of Napoleon lead a life full of risks and sometimes the list of injuries a soldier could have during his entire life was absolutely impressive. Marshall Nicolas-Charles Oudinot (1767-1847) was injured about 25 times during his military career: ${ }^{22}$

- 1793: ball in the head (Haguenau)

- 1794: leg broken by ball (Trèves)

- $\quad$ 1795: five saber cuts, one ball (Neckarau)

\footnotetext{
90 Cardoza, Intrepid women, pp. 1-2.

91 Ibid. p. 2.

92 Haythornthwaite and Courcelle, Napoleon's commanders, p. 47.
} 
- 1796: four saber cuts, one ball (Ingolstadt)

- 1799: ball in chest (Rosenberg), ball in shoulder blade (Schwyz), ball in chest (Zürich)

- 1805: ball in thigh (Hollabrunn)

- 1807: leg broken when horse fell (Danzig)

- 1809: saber cut (Essling), ear nearly shot off (Wagram)

- 1812: grapeshot in shoulder (Polotsk), ball through body and dragged (Berezina)

- 1814: cannon ball grazes both thighs (Brienne), ball in chest (Arcis-sur Aube): Of particular interest is that this last wound was less serious because it was deflected by his decoration of the Legion of Honor

Maybe receiving 10 saber cuts during your entire military career sounds like a lot, but not one soldier probably received more saber cuts than colonel Chipault of the 4th Cuirassiers who had received 52 sabre cuts in the battle of Heilsberg (10 June 1807). He fainted from bloodloss but, after recovering, continued to serve his country. ${ }^{93}$

\section{VI.2. Saber wounds treated and cured by Dominique Larrey (1766-1842)}

In his famous work Mémoires de chirurgie militaire et campagnes (Memories on military surgery and campaigns) Dominique Larrey (1766-1842) describes many of his operations on wounded soldiers. Most of the wounds Larrey and his assistants had to treat were caused by guns, but we can also find many references to wounds caused by sabers. Larrey himself was even wounded twice (on the head) and on the left shoulder by a saber at the battle of Waterloo, when he was trying to flee and even defended himself with his own two pistols and saber. ${ }^{94}$

It is interesting to note that the wounds caused by edged weapons, even on the head, usually healed without problems and also quite quickly.

\footnotetext{
${ }^{93}$ Nougaret, Anecdotes militaires, anciennes et modernes, des Français, p. 305.

${ }^{94}$ Larrey, Mémoires de chirurgie militaire et campagnes, II p. 974.
} 


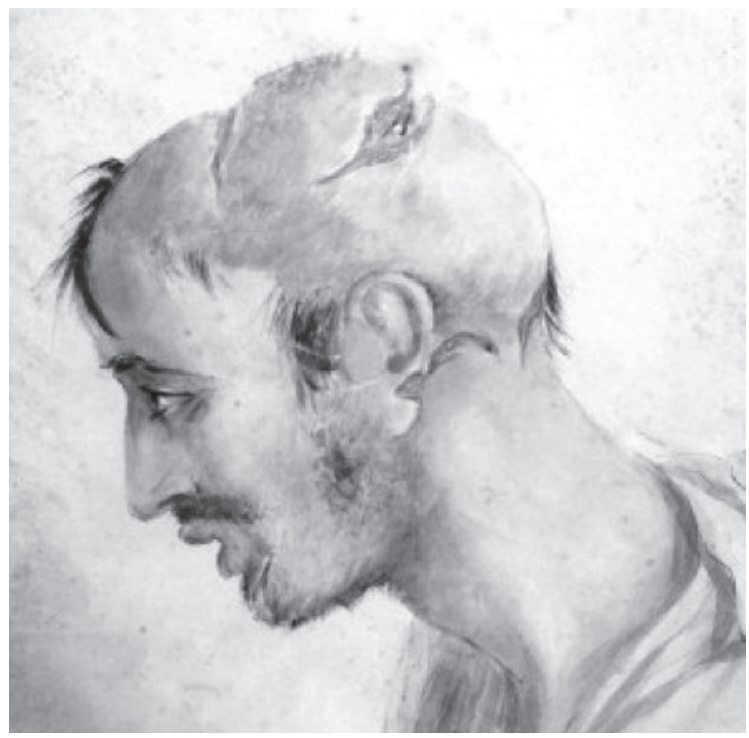

Figure 24: Soldier suffering from head and facial injuries, profile inscribed "Waterloo".

Sabre wound to head,

Hospital de la Gendarmerie, 5 July 1815.

On the image can been seen that the head is shaven to make the treatment, usually suturing and bandaging, more easy.

Watercolour 1836 by Charles Bell

The RAMC Muniment Collection in the care of the Wellcome Library, Wellcome Images

In 1799, during the Egyptian campaign, lieutenant-colonel Paultre received several saber cuts and the thrust of a lance but he recovered after six weeks. ${ }^{95}$ More serious was the wound of Pierre Soult, member of the $22^{\text {nd }}$ Chasseurs, who obtained a heavy saber wound from a Mameluke in his occipital bone (back bottom of the skull). This cut divided the extensor muscles of his head as far as the sixth vertebra at which point the spinous process was cut. An enourmous piece of skin was hanging on his shoulders and his chin fell on his chest. Though this wound looked horrible, Larrey sutured the infection and bandaged it. The patient was fully recovered after a short amount of time, though Larrey adds in a footnote that the soldier could not produce any children anymore after suffering from this wound. ${ }^{96}$

This Mameluke cut was clearly meant to cut off the head of the French soldier, but soldiers might not only lose their head in battle. Larrey gives several examples of operations in which the faces of soldiers were afflicted by saber wounds but nevertheless could be treated succesfully by suturing: Gardel (nose, cheek and part of his jaw bone),

\footnotetext{
95 Larrey, Mémoires de chirurgie militaire et campagnes, I p. 212.

96 Ibid., I, p. 280.
} 
Thévenin (eyebrow, eyelid, cheekbone and cheek), Pierre Leclerc (nose and cheek), Jerdet and Lejuste (nose) and Rivière Brocard (left part of head near the ear). ${ }^{97}$ General Dommanget received serveral saber blows in the battle of Moscow (1812), several cuts on his scalp, one on his lip and even a cut which damaged several teeth and made him look horrible and unrecognisable. Larrey removed several broken teeth, sutured the lip and the general could return to France. Later only a small scar was seen on his lip, but no other deformity. ${ }^{98}$ Larrey was also successful in operating on the nose of a Russian colonel without leaving any deformity afterwards. ${ }^{99}$ It is interesting to note that Larrey likes to add that he performed an operation which left the patient afterwards without any scar or only a small scar. Surprisingly not many images can be found of soldiers and officers with scars on their heads,as a result of saber wounds.

To my knowledge, only three clear images exist, which I present here:

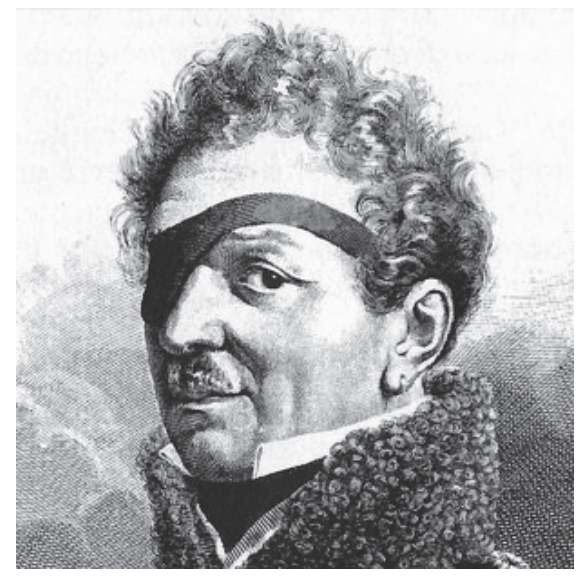

Figure 25: Adam Adalbert von Neipperg (1775-1829) was heavily wounded in 1794: bayonet thrust in the right arm and saber cut on his right eye. (Allgemeine Deutsche Biographie, 1886, 23, c. 408)

Source:

bttp:/ / en.wikipedia.org/wiki/_Adam_Albert_von_Neipperg\#/ media/File:Neipperg.jpg (accessed 6 May 2015).

\footnotetext{
${ }^{97}$ Ibid., I, pp. 590-592.

98 Ibid., II, p. 1148.

${ }^{99}$ Ibid., II, pp. 734-735.
} 


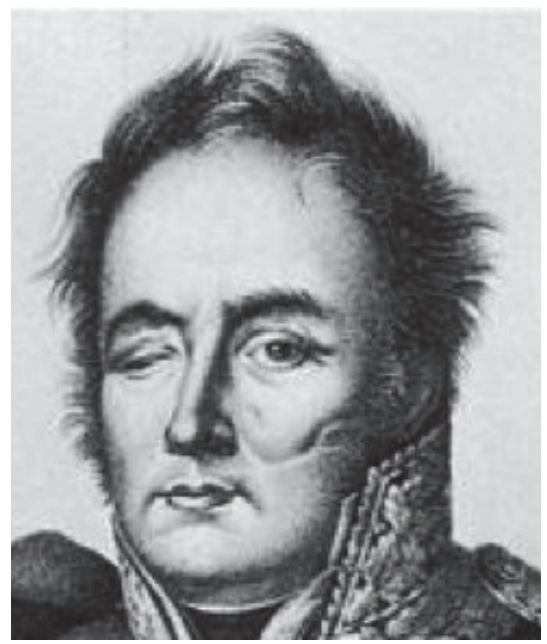

Figure 26: During the Battle of Waterloo, Pierre-François Durutte (1767-1827), commander of the 4th devidion received two heavy saber blows: one in the face and one on the right hand, which had to be amputated the day after.

Source: http://fr.wikipedia.org/wiki/Pierre_Francois_Joseph_Durutte (accessed 6 May 2015).

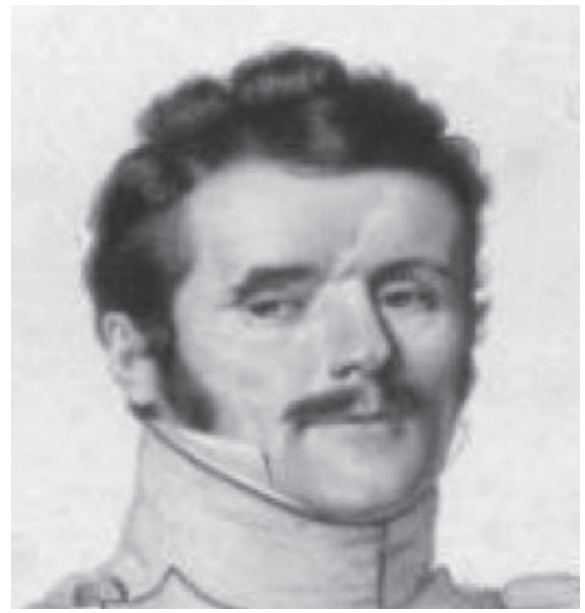

Figure 27: Joachim Hyppolite Lepic (1768-1835), brother of the famous general Lepic, received several saber cuts in his entire career.

On this image one can clearly see the scar on his face, made by a saber in June 1807.

Source: http:/ / fr.wikipedia.org/wiki/Joachim_Hippolyte_Lepic (accessed 6 May 2015).

But not only the upper part of the body was a target. François Bernard was wounded by a saber in his lower abdomen. Some of the intestines had already come out, but Larrey 
put them back and the patient survived after six weeks. ${ }^{100}$ During the Russian campaign (1812) Larrey had to operate on a certain Arbette, who received a saber thrust in his lower abdomen. Though the patient suffered terribly from inflammation, he did recover after about one month. ${ }^{101}$ Larrey also mentions the case of officer Netherwood who received a very deep cut from a Mameluke during the Egyptian campaign. A Mameluke saber cut him very deep in the right thigh but Larrey sutured Netherwood with about ten stitches, after which the patient walked as before. ${ }^{102}$

In certain cases, certainly when surgeons feared the risk of gangrene, ${ }^{103}$ an amputation of the wounded member was necessary, as the case of colonel Sourd illustrates. Sourd was colonel of the $20^{\text {th }}$ regiment of the Chasseurs à cheval and was wounded several times by saber cuts on the right arm. Two wounds were situated on the joints of the wrist and the elbow but a third cut had gone through the muscles in the arm until it reached the bone. Larrey and his assistants judged that an amputation was necessary and performed the operation, during which Sourd did not show any signs of pain and even dictated a letter to the Emperor asking that he be able to keep command of his regiment. The bandage was only just attached when Sourd mounted and went back to the battle and survived. ${ }^{104}$ Sometimes amputation wasn't a success and the patient died immediately after, as the case of Joseph Grandi illustrated when he received a saber cut in the joint of his right knee. ${ }^{105}$ The patient could also die after a few days: Jean Lapaix also suffered from a saber cut in his right knee. Lapaix asked for the amputation after five days, and in the beginning he seemed to heal but after fifteen days he died anyway. Larrey adds that he had seen many similar cases of people dying because the doctors were afraid to amputate. ${ }^{106}$

\footnotetext{
100 Ibid., I, p. 592.

101 Ibid., II, p. 865.

102 Ibid., II, p. 1172.

103 Ibid., I, pp. 455 and 642-643.

104 Ibid., II, pp. 973 and 1182.

105 Ibid., I, p. 443.

106 Ibid., I, pp. 443-444.
} 


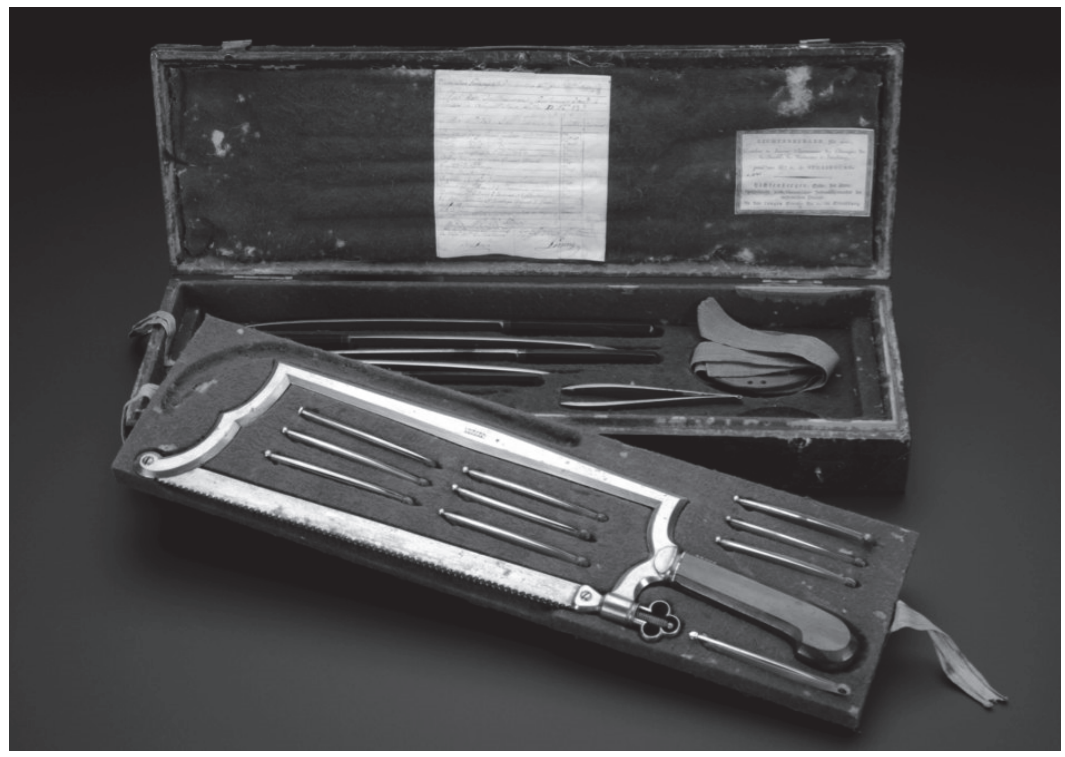

Figure 28: Amputation instrument set, Strasbourg, France, 1780-1820

Source: Science Museum London

$\leq$ http:// www.sciencemuseum.org.uk/ broughttolife/objects/display.aspx?id $=5476>$ (accessed 6 May 2015)

The example of Sourd illustrates that the wrist and arm were a possible target and these are also the body parts where Pierre Larrey was wounded in 1810. Because Larrey saw inflammation of the wound, he executed the amputation in less than one minute and his patient survived. ${ }^{107}$

The most bizzare wound treated by Larrey happened during the second battle of Aboukir (1799). When general Dermoncourt was leading his troops, his saber was broken by a large musket ball. The broken saber blade flew through the air and struck a soldier behind Dermoncourt in his thigh penetrating about 4 to $5 \mathrm{~cm}$ deep. When other soldiers saw this wound, they were very angry at the enemy because they thought they charged their cannons with broken saber blades. Larrey added to this story that he explained to the soldiers what really had happened and that this wound was not so special for him because he had seen many similar cases during his entire campaign. Larrey also added that the healing of the soldier occured without any problem. ${ }^{108}$

107 Ibid., I, p. 280.

108 Ibid., II, p. 1142. 


\section{VI.3. Protection against saberblows to the head}

Because many saber cuts were aimed at the head, soldiers wore shakos or sometimes even leather helmets, reinforced with a brass band. ${ }^{109}$ The anecdote of Marbot in Spain illustrates how even simple shakos, without brass or iron bands, could provide a certain way of protection against blows to the head. Cuirassiers and carabiniers had beautifully decorated steel helmets which provided better protection.

Of course head protection could be lost, so a very popular method of giving extra protection to the head were the so called cadenettes: braids on both side of the head, sometimes around a wooden core. These cadenettes partially protected the side of the face against saber cuts. ${ }^{110}$

\section{OTHER WAYS OF USING THE SABER: PUNISHMENT AND PRIZE}

Sometimes the flat of the blade was used to punish prisoners, or as in the case of MarieThérèse Figueur, the flat was used to encourage her not to slow down when she was taken away as prisoner. ${ }^{111}$

Sergeant Bourgogne tells the story about a Russian officer who uses the flat of his saber on his own soldiers who where trying to flee from the battlefield. ${ }^{112}$

When he was still general, Napoleon had the custom of giving honorary swords and pistols to brave and valliant soldiers. There was some discussion as to whether he really had the authority to do so, but nevertheless, he gave valuable, beautifully decorated and inscribed weapons to his soldiers as early as 1797 (In the Italian campaing he had given about one hundred sabers to his heroes) and in $1798 .{ }^{113}$ In this practice, Napoleon was not an innovator because, already in 1796 , the Directory government had started to give ornate weapons to brave soldiers or units. ${ }^{114}$

\section{AND NAPOLEON HIMSELF?}

Unfortunately not much can be found about Napoleon's own martial skills. As a young boy of ten years old, he went to the Ecole Militaire royale in Brienne-le-Château, near Troyes in the Champagne region. Every day the young students had eight hours of course: mathematics, Latin, history, German, geography, natural sciences, science of fortifications

${ }^{109}$ Crowdy, Napoleon's infantry handbook, p. 72.

110 Ibid., p. 78.

111 Figueur, Les campagnes de mademoiselle Thérèse Figueur, p. 107.

112 Bourgogne, Mémoires du sergent Bourgogne, p. 112.

113 Crowdy, Napoleon's infantry handbook, pp. 135-136 and Gallaher, Napoleon's enfant terrible, p. 112

114 Crowdy, Napoleon's infantry handbook, p. 136. 
and of weapons, dancing, music and also fencing. In 1784 Napoleon graduated at Brienne and was admitted to the very prestigiuos Ecole Royale Militaire near the Seine in Paris. Here he had the same courses as in Brienne, but without history of strategy and battle. New courses were musket shooting, military marching and horse riding. ${ }^{115}$ In Brienne his achievements in fencing and dancing had been marked as 'very poor', but in Paris he became better and was known for the amount of blades he had broken. ${ }^{116}$

After the graduation of Napoleon at the Ecole Royale, there is not one reference to Napoleon's personnal achievements with the saber, though he had a huge collection of decorated sabers - even one in his coffin. ${ }^{117}$ - and is almost always depicted with a saber or smallsword.

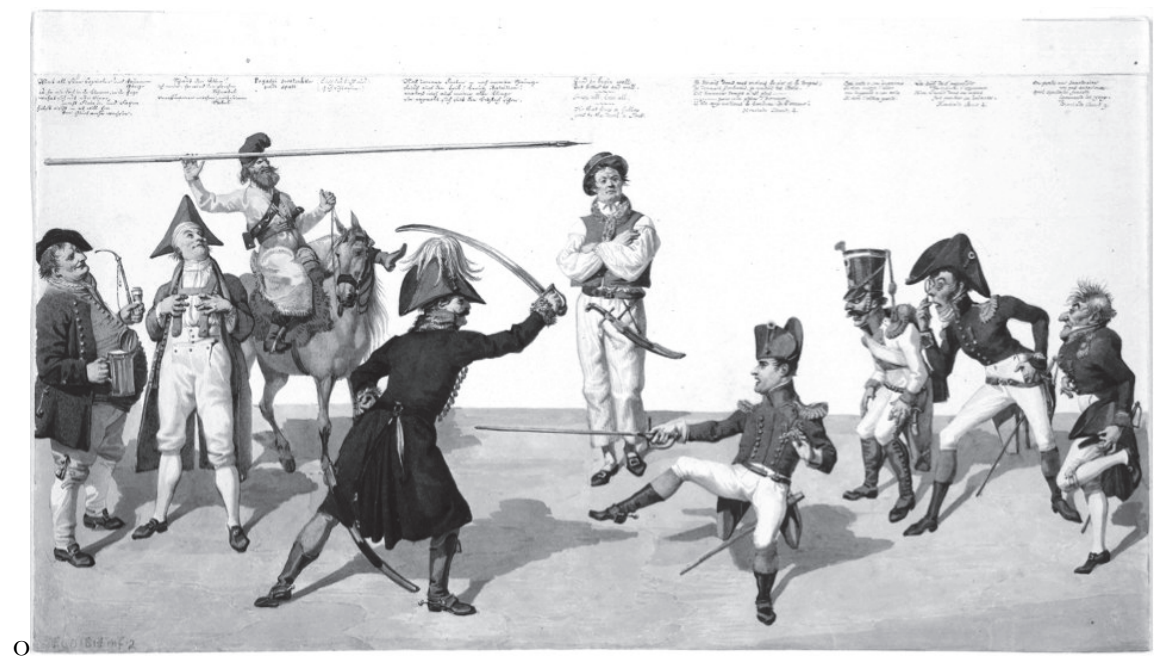

Figure 29: The fencing lesson: Little (though he was $1 \mathrm{m68}$, which was an average height in his time) Napoleon is fencing against von Blücher while a British sailor is juding the match. Blücher is supported by German peasants and even a Russian cossack.

Ink and watercolour caricature made by the Prussian artist Johann Gottfried Shadow Source: World digital Library (<http:/ / www.wdl.org/en/item/2944/> , accessed 6 May 2015)

One notable exception can be found at the end of Napoleon's military career. In the Battle of Arcis-sur-Aube (20 March 1814), the emperor himself was at the head of his

115 Roberts, Napoleon de Grote, pp. 32 and 38.

116 Cohen, By the sword, p. 96.

117 Op de Beeck, Napoleon, deel II, p. 728. 
own troops and fought, saber in hand. It is very well possible that he was searching for his death on the battlefield, but could not find it. ${ }^{118}$

In contrast to many of his officers (Ney, Marbot, Augereau, baron de Lasalle,...) there are no stories about Napoleon involved in duelling. When people challenged him to a duel, he simply declined, as was the case when the king of Sweden challenged him to duel with him. ${ }^{119}$ According to Mike Loades, Napoleon would have said: "It's too bad that death often results from duelling, for duels otherwise help keep up politeness in society." 120 Though this quote seems to say that Napoleon didn't have any problems with duelling, in reality he saw this as a waste of manpower. According to Elting "he especially disliked the professional duellist, whom he compared to a cannibal."121 Cohen also confirms this negative view of Napoleon against duelling: a good duellist made a bad soldier and besides this, many soldiers in his army had died or were seriously injured because of a matter of honour. ${ }^{122}$ Parquin tells an interesting story about Napoleon's opposition against duelling. When the emperor saw the huge scar on the face of Captain Lion, which was caused by duelling, he asked him where the scar came from. Lion replied that it happened in Ulm. On hearing this, the emperor rewarded him because he thought it happened during the Battle of Ulm (16-19 October 1805). Lion didn't lie, because he received the wound in Ulm, not on the battlefield but in a duel... If the emperor had known this, he would never have rewarded Lion. ${ }^{123}$

\section{CONCLUSION}

Without any doubt, the saber was not the most deadly, but certainly the most honourable weapon during Napoleonic warfare. Even today, it is still an iconic weapon, symbolizing the personal contact between two warriors, in which bravery and martial prowess played an important role. A scar obtained from a saber was not something to wear with shame, but was a proud mark of bravery on the battlefield or in a personal duel.

Though it was not the most deadly weapon, it still played an important role in the hands of an experienced cavalry soldier. Here, in combination with the speed and weight of a horse, and wielded by a large group of cavalrists it was the conditio sine qua non for a successful cavalry charge. These charges, as proven in the Battle of Eylau, could change the course of a battle from defeat into victory.

\footnotetext{
118 Ibid. p. 530.

${ }^{119}$ Cohen, By the sword, p. 97.

120 Loades, Swords and swordsmen, p. 459.

121 Elting, Swords around a throne, p. 97.

122 Cohen, By the sword, p. 97.

123 Parquin, Récits de guerre, p. 43.
} 
In this article, I have selected only a few stories of martial prowess, in which individual soldiers survived or became famous because of their talent in wielding the saber. Still, many more individual stories are waiting for scholars to be discovered. ${ }^{124}$

Are there conclusions to be made for people practising military saber in the world of Historical European Martial Arts? This research has certainly proven that in combat the afterblow was very frequent: hitting someone on the head certainly didin't cause his death - as in the case of Louis-Ferdinand - and it was very important to riposte the attack of a wounded opponent. It was also very difficult to leave a saber duel unharmed, wounds occurred frequently, but good surgeons could easily treat these. The fact of bein being wounded in a battle, even on the head, and continuing to fight, is something which can never be imitated in HEMA, where the use of sharp weapons is not possible and where no napoleonic uniforms are worn. Some questions will certainly be unanswerd: How sharp were individual blades of individual soldiers? How resistant was their body (covered in leather or other clothing) to a deep cut? When did soldiers feel pain enough to leave the battlefield? Personally, I strongly believe there is an uncrossable gap between our present day HEMA and the world of napoleonic soldiers who fought under harsh conditions, whose survival was dependent from their use of the sword, who wanted to achieve glory on the battlefield and shine in the eyes of their commanders or give the example in front of their men. Those are things from the past and can never return or simulated in a present day saber bout.

On the other side, it is possible today to set up rules concerning the target zone (head only or also other parts of the body?), the kind of hit (with a thrust or with a cut?), the amount of protection (fencing jacket, gloves or only fencing mask?) and concerning the afterblow (one, two or three afterblows?).

I also think it can be very valuable and interesting to experiment with different kind of sabers, because the French soldiers had to fence against Mamelukes with very curved sabers or cuirassiers with straight swords. Maybe this could be a challenge for the future of the military saber in HEMA?

\section{BIBLIOGRAPHY}

\section{X.1. Primary Literature}

Adrien Bourgogne, Mémoires du sergent Bourgogne (1812-1813), publiés d'après le manuscrit original, ed. by Paul Cottin and Maurice Hénault (Paris: Librarie Hachette et Compagnie, 1853, repr. 1910).

124 An enormous amont of primary sources (more than 5000) is presented by the Fondation Napoleon, see: <http://www.napoleon.org/en/home.asp>. 
Alexandre Muller, La baïonette et son maniement: L'escrime militaire au début du XIXe siècle. Alexandre Muller (Manuel d'Instruction: vol. 1), ed. by Philippe Charlet and Jean-Jacques Pattyn (Gilly: Historic 'One, 2013).

Alexandre Muller, Le sabre et l'escrime du cavalier: L'escrime militaire au début du XIXe siècle. Alexandre Muller (Manuel d'Instruction: vol. 2), ed. by Philippe Charlet and Jean-Jacques Pattyn (Gilly: Historic 'One, 2013).

Antoine Charles Etienne de la Roche-Aymon, Troupes Légères, ou réflexions sur l'organisation, l'instruction et la tactique de l'infanterie et de la cavalerie légères (Paris : Magimel, Anselin et Pochard, 1817)

Antoine Fortuné de Brack, Light cavalry out-posts: Recollections by F. De Brack, translated from the fifth edition for F.M. The marquis of Tweeddale, ed. by Lonsdale A. Hale and F.T. Hobson (London: W. Mitchell \& Co. Military Publishers, 1876).

Denis Charles Parquin, Récits de guerre: Souvenirs du capitaine Parquin 1803-1814 (Paris: Boussod, Valadon et Compagnie, 1842, repr. 1892).

Dominique Larrey, Mémoires de chirurgie militaire et campagnes, I 1787-1811: Campagnes de l'Amérique Septentrionale, du Rhin, de Corse, des Alpes-Maritimes, de Catalogne, d'Italie, d'Egypte et de Syrie, de Boulogne, d'Ulm et d'Austerlits, de Saxe, de Prusse, de Pologne, d'Espagne et d'Autriche avec planches (Paris, Tallendier Editions, 2004).

Dominique Larrey, Mémoires de chirurgie militaire et campagnes, II (Campagnes de Russie, de Saxe, et de France, relation Médicale de campagnes et voyages, annexes avec planches (Paris, Tallendier Editions, 2004).

Friedrich Christian Christmann and G. Pfeffinger: Theoretisch-Praktische Anleitung des Hau und Stossfechtens und des Schwadronhauens nach einer ganz neuen Methode bearbeitet (Offenbach am Main: Pfeffinger (?), 1838).

Jean Baptiste Antoine Marcellin de Marbot, The memoirs of Baron de Late, ed. by Arthur John Butler (London: Forgotten Books, 2013).

Jean-Roch Coignet, Les cahiers du capitaine Coignet (1799-1815) publiés par Lorédan Larchey, d'après le manuscrit original avec gravures et autographe fac-similé, ed. by Lorédan Larchey (Paris : Librairie Hachette et Compagnie, 1883).

Joseph Abbeel, Met Napoleon naar Moskou: De ongelooflijke overlevingstocht van Joseph Abbeel, ed. By Joost Welten and Johan De Wilde (Leuven: Davidsfonds, 2011).

Louis Rilliet, Journal d'un sous-lieutenant de cuirassiers 1810-1814, présenté et annoté par Olivier Lapray (Editions du Grenadier), ed. by Olivier Lapray (Paris : Bernard Giovanangeli Editeur, 2013).

M.J. de Saint Martin, L'art de faire des armes réduit à ses vrais principes (Vienna: Imprimerie de Janne Schrämble, 1804).

Nicolas Davout, Le Maréchal Davout, Prince d'Eckmühl. Correspondance Inédite, 1790-1815 Pologne- Russie- Hambourg, ed. by Adélaide Louise d' Eckmühl de Blocqueville (London: Forgotten Books, 2013). 
Pierre Jacques François Girard, Nouveau traité de la perfection sur le fait des armes, dédie au roy, par le Sr. P.J.F. Girard, ancien officier de marine, enseignant la manière de combattre de l'épee de pointe seule, toutes les gardes étrangeres, l'espadon, les piques, hallebardes, bä̈onettes au bout du fusil, fléaux brisés et batons à deux bouts; ensemble à faire bonne grâce les saluts de l'esponton, l'exercice du fusil, et celui de la grenadière, tels qu'ils se pratiquent aujour'bui dans l'art militaire de la France (Paris: Moette, 1736).

Pierre Jean Baptiste Nougaret, Anecdotes militaires, anciennes et modernes, des Français; contenant les actions sublimes et courageurses des généraux, des grands capitaines, des officiers et des soldats, les traits de dévouement extraordinaire de plusieurs villes assiégées, des particularités sur plusieurs batailles mémorables, soit de terre, soit de mer, et sur les stratagèmes de guerre curieux et remarquables (Paris, F. Louis, 1808).

Thérèse Figueur, Les campagnes de mademoiselle Thérèse Figueur, aujourd'bui Madame Veuve Sutter, ex-dragon aux 15 e et 9 e régimens, de 1793 a 1815, écrites sous sa dictée par St.-Germain Leduc (Paris: Dauvin et Fontaine, 1842).

\section{X.2. Secondary sources}

Amberger, Christopher, The secret history of the sword: Adventures in ancient martial arts (Burbank: Multi-Media Books, 1999).

Amberger, Christopher, Saber fencing: Germany, 1838 (2008), available from Fencingclassics $<$ https:/ / fencingclassics.wordpress.com/2008/12/05/saber-fencing-germany1838/ $\geq$ (accessed 4 April 2015).

Amberger, Christopher The French connection: Christmann's practical self-defence (2011), available from Fencingclassics <https:/ / fencingclassics.wordpress.com/2011/12/06/the-french-connectionchristmanns-practical-self-defence/> (accessed 4 April 2015).

Barbero, Alessandro, Waterloo. Het verhaal van de veldslag (Amsterdam: Mets \& Schilt Uitgevers, 2010).

Briost, Pascal., Hervé Drévillon and Pierre Serna,Croiser le fer. Violence et culture de l'épée dans la France moderne (XVIe-XVIIIe siècle) (Les Classiques de Champ V allon) (Seyssel: Champ Vallon, 2002).

Cardoza, Thomas, Intrepid women. Cantinières and vivandières of the French army (Indiana: Indiana University Press, 2010).

Cohen, Richard, By the sword: gladiators, musketeers, samurai, swashbucklers, and Olympic champions (London: Simon and Schuster UK Ltd, 2010).

Crowdy, Terry E., Napoleon's infantry handbook (Yorkshire: Pen and Sword Military, 2015).

Elting, John.R., Swords around a throne: Napoleon's Grande Armée (New York: Da Capo Press, 1988, repr. 1997).

Fermont Barnes, Gregory (ed.), Encyclopedia of the French Revolutionary and Napoleonic Wars. A political, social and military history (Santa Barbara, Denver and Oxford: ABC Clio, 2006). 
Gallaher, John G., Napoleon's enfant terrible: General Dominique V andamme (Campaigns and commanders 15) (Oklahoma: University of Oklahoma Press, 2008).

Haythornthwaite, Philip (text) and Patrice Courcelle (Illustrations), Napoleon's commanders (1) c. 1809-15 (Osprey Elite 72) (Oxford: Osprey Publishing, 2001).

Haythornthwaite, Philip (text) and Patrice Courcelle (Illustrations), Napoleon's commanders (2) c. 1809-15 (Osprey Elite 83) (Oxford: Osprey Publishing, 2002).

Haythornthwaite, Philip, Napoleonic cavalry (Napoleonic weapons and warfare) (London: Cassell, 2002).

Histoire de la guerre d'Espagne contre Napoleon Buonaparte, par une commission d'officiers de toutes armes établie à Madrid auprès de S. Ex. Le ministre de la guere, tome I. (Paris: Le Normant, 1818).

Hughes, Basil P., Firepower: weapons effectiveness on the battlefield 1630-1850 (New York: Sarpedon, New York, 1997).

Loades, Mike, Swords and swordsmen (Yorkshire: Pen and Sword Military, 2010).

Massoni, Gérard-Antoine, Histoire d'un régiment de cavalerie légère : le 5e hussards 1783-1815 (Paris: Archives \& Culture, 2008).

Napoleon, his army and enemies: armies - battles- tactics- commanders, Napoleon's guard cavalry, available from Napoleonistyka

<http://napoleonistyka.atspace.com/IMPERIAL_GUARD_cavalry_1.html> (accessed 15 April 2015).

Napoleon, his army and enemies: armies - battles- tactics- commanders, Infantry tactics and combat during the Napoleonic wars, part 1, available from Napoleonyska <http://www.napolun.com/mirror/napoleonistyka.atspace.com/infantry_tactics_2. htm $>$ (accessed 15 April 2015).

(1886) 'Neipperg, Adam Adalbert Graf von', Allgemeine Deutsche Biographie (Leipzig: Duncker und Humbolt, 1886), vol. 23, c. 408-412.

Nosworthy, Brent, With musket, cannon and sword: battle tactics of Napoleon and his ennemies (London: Da Capo Press, 1996).

Op de Beeck, Johan, Napoleons nachtmerrie. 1812: hoe de Keizer en zïn soldaten ten onder gingen in Rusland (Berchem: Epo, 2012).

Op de Beeck, Johan, Napoleon, deel I: Van strateeg tot keizer (Amsterdam: Manteau, 2014).

Op de Beeck, Johan, Napoleon, deel II: Van Keizer tot mythe (Amsterdam: Manteau, 2014).

Pawly, Ronald (text) and Patrice Courcelle (illustrations), Napoleon's carabiniers (Men-atArms 405). (Oxford: Osprey Publishing, 2005).

Pawly, Ronald (text) and Patrice Courcelle (illustrations), Napoleon's mamelukes (Men-atArms 429). (Oxford: Osprey Publishing, 2006).

Roberts, Andrew, Napoleon de Grote (Amsterdam: Prometheus, 2015).

Reinhard, Hank, The book of swords (New York: Baen Books, 2009). 
Roucaud, Michel., 'Etude des Avant-postes de cavalerie légère par le général de Brack', Revue Historique des Armées 249 (2007) pp. 110-113.

SabresEmpires, Napoleonic swords and sabers collection, available from Swordscollection <http://swordscollection.blogspot.co.uk/2012/02/my-napoleonic-swordcollection.html> (accessed 15 April 2015).

Westwood, David, 'French Army' in Gregory Fermont Barnes (ed.), Encyclopedia of the French Revolutionary and Napoleonic W ars. A political, social and military history (Santa Barbara, Denver and Oxford: ABC Clio, 2006) pp. 373-378.

Westwood, David, 'musket' in Gregory Fermont Barnes (ed.), Encyclopedia of the French Revolutionary and Napoleonic Wars. A political, social and military history (Santa Barbara, Denver and Oxford: ABC Clio, 2006) pp. 668-669.

Westwood, David, 'rifle' in Gregory Fermont Barnes (ed.), Encyclopedia of the French Revolutionary and Napoleonic Wars. A political, social and military history (Santa Barbara, Denver and Oxford: ABC Clio, 2006) pp. 373-378.

Westwood, David, 'Musket' in Gregory Fermont Barnes (ed.), Encyclopedia of the French Revolutionary and Napoleonic W ars. A political, social and military history (Santa Barbara, Denver and Oxford: ABC Clio, 2006) pp. 818-819.

Wikipedia, Joachim Hyppolite Lepic, available from Wikipedia < http://fr.wikipedia.org/wiki/Joachim_Hippolyte_Lepic> (accessed 6 May 2015).

Wikipedia, The Duellists, available from Wikipedia < http://en.wikipedia.org/wiki/The_Duellists> (accessed 6 May 2015).

Wikipedia, Pierre François Durutte, available from Wikipedia <http://fr.wikipedia.org/wiki/Pierre_François_Joseph_Durutte> (accessed 6 May 2015). 